\title{
MUSIC TRACKS \\ Cultural Diversity and the Practices of Mobile Architecture
}

\author{
Mu-Chih, Peter, Fan Chiang
}

A thesis submitted to the Faculty of Graduate Studies and Research in partial fulfillment of the requirements, for the degree of Master of Architecture

Carleton University, Ottawa, Canada

May, 2009

Peter Fan Chiang (C) 2009 


\section{Library and \\ Archives Canada \\ Published Heritage \\ Branch \\ 395 Wellington Street \\ Ottawa ON K1A ON4 \\ Canada \\ Bibliothèque et \\ Archives Canada \\ Direction du \\ Patrimoine de l'édition \\ 395, rue Wellington \\ Ottawa ON K1A ON4 \\ Canada}

Yourfile Votre référence

ISBN: 978-0-494-52098-7

Our file Notre référence

ISBN: 978-0-494-52098-7

NOTICE:

The author has granted a nonexclusive license allowing Library and Archives Canada to reproduce, publish, archive, preserve, conserve, communicate to the public by telecommunication or on the Internet, loan, distribute and sell theses worldwide, for commercial or noncommercial purposes, in microform, paper, electronic and/or any other formats.

The author retains copyright ownership and moral rights in this thesis. Neither the thesis nor substantial extracts from it may be printed or otherwise reproduced without the author's permission.
AVIS:

L'auteur a accordé une licence non exclusive permettant à la Bibliothèque et Archives Canada de reproduire, publier, archiver, sauvegarder, conserver, transmettre au public par télécommunication ou par l'Internet, prêter, distribuer et vendre des thèses partout dans le monde, à des fins commerciales ou autres, sur support microforme, papier, électronique et/ou autres formats.

L'auteur conserve la propriété du droit d'auteur et des droits moraux qui protège cette thèse. $\mathrm{Ni}$ la thèse ni des extraits substantiels de celle-ci ne doivent être imprimés ou autrement reproduits sans son autorisation.
In compliance with the Canadian

Privacy Act some supporting forms may have been removed from this thesis.

While these forms may be included in the document page count, their removal does not represent any loss of content from the thesis.
Conformément à la loi canadienne sur la protection de la vie privée, quelques formulaires secondares ont été enlevés de cette thèse.

Bien que ces formulaires aient inclus dans la pagination, il n'y aura aucun contenu manquant. 


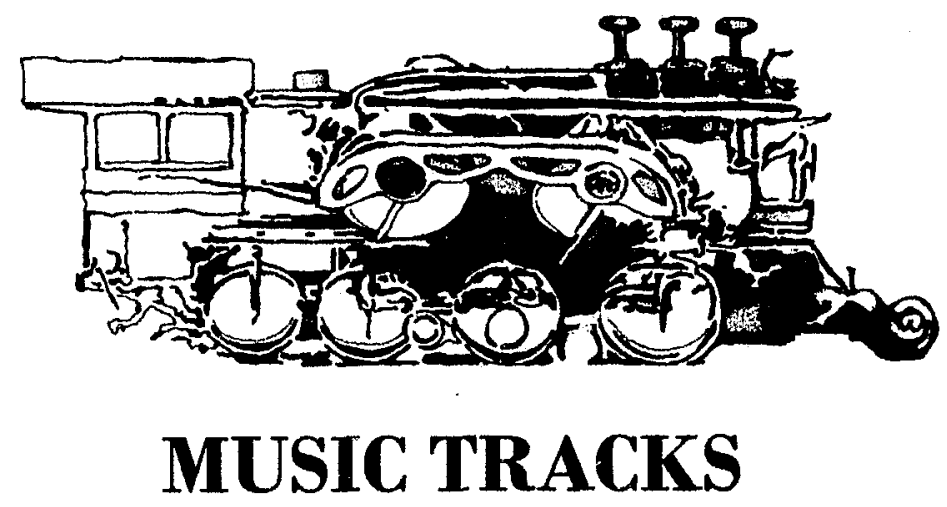




\begin{abstract}
Transcontinental railroads played an important role in the formation of Canada in the late nineteenth century. Settlers from various parts of Europe were carried by steam trains to different regions of Canada. Towns and cities sprawled from train stations and multiple ethnic groups were distributed along railroads. After many decades of the discovery of the New World, Canadian society, consisting of many co-existing identities within its national borders, became a collage of ethnic faces. Music activities were the expressions of those faces.
\end{abstract}

This thesis proposes that music events - with the character of representing different cultural identities - should constantly participate in re-shaping and moulding the Canadian culture as a whole. In so doing, this thesis will not only criticize the conventional music tour carried by train, but will also explore the application of mobile architecture (facilitated by existing rail infrastructure) as a circulation mechanism to carry performers throughout the country. The design portion of this thesis proposes an annual cross-country music festival, 'Music Tracks,' which will be staged at two selected train yards in both Ottawa and Vancouver. In the summer, twenty selected music bands across Canada will travel separately from their own towns to the Ottawa festival site by train. They will make stops and perform in small towns along railroads. Their sleeper carriages are designed to be connected together and to be transformed into temporary residences and a concert stage. After a series of concerts in Ottawa, the bands will travel all together to Vancouver's festival site to setup their festival once again. Portable architecture for traveling musicians, hence, is a mechanism to promote the diversity of our cultural expression; at the same time, it enhances the cultural integrity within the political borders of Canada. 
List of Tracks

List of Illustrations 4

$\begin{array}{ll}\text { Introduction } & 6\end{array}$

$\begin{array}{ll}\text { - DO - } & 8\end{array}$

$\begin{array}{ll}\text { Track 1: The Beginning } & 8\end{array}$

Track 2: Gateway to Prairie Towns 11

$\begin{array}{ll}\text { Track 3: A Collage of Faces } & 14\end{array}$

$\begin{array}{ll}- \text { RE - } & 18\end{array}$

Track 4: The Heartbeat of a People $\quad 18$

Track 5: The Blood Vessels of a Land 20

Track 6: The Fall of the Railway Empire $\quad 24$

Track 7: Diversity within an Integrity 29

Track 8: A Western Odyssey 33

$\begin{array}{ll}- \text { ME - } & 43\end{array}$

Track 9: A Proposal for the Future $\quad 43$

$\begin{array}{ll}\text { Track 10: The Legend Continues } & 67\end{array}$

$\begin{array}{ll}\text { Bibliography } & 69\end{array}$ 


\section{List of Illustrations}

Fig. 1 Dominion of Canada, 1867, the Railways and their principal connections................10

Fig. 2 European Farmers: at CPR Station in Winnipeg...................................................................13

Fig. 3 Adam - One Blood, Many nations: Painted by Lewis Lavoie ............................................17

Fig. 4 Canadian National Railways route map …................................................................................23

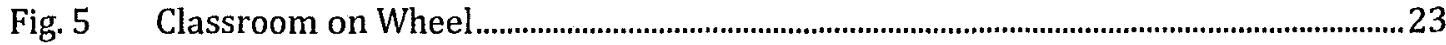

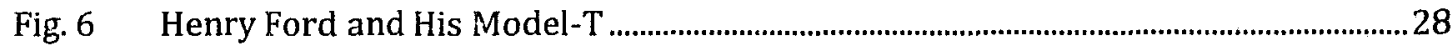

Fig. 7 Distribution of Population in Canada, 1956 ......................................................................38

Fig. 8 Population Distribution as of July 1, 2007: by Census Division (CD), Canada ..........38

Fig. 9 Festival Express: Screenshots from Festival Express Documentary DVD ..................39

Fig. 102008 Holiday Train Route Map …..................................................................................40

Fig. 11 Holiday Train: Concert at La Crosse ................................................................................41

Fig. 12 Holiday Train: Stage Converted from a Box Car...................................................................41

Fig. 13 Barnum \& Bailey greatest show on Earth Poster ...................................................................42

Fig. 14 Proposed Festival Route for 'Music Tracks' .............................................................................49

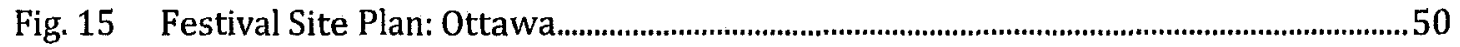

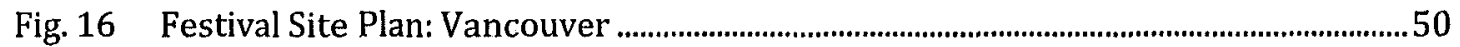

Fig. 17 Perspective View of 'Music Tracks' ............................................................................................51

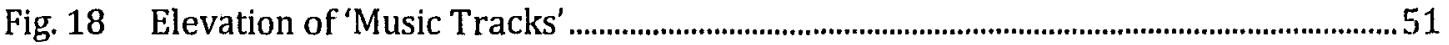

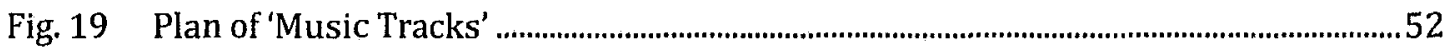

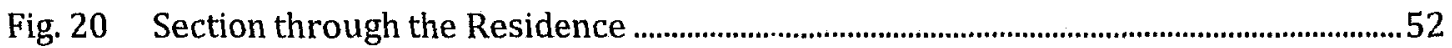

Fig. 21 Section through the Audience Platforms ..........................................................................5

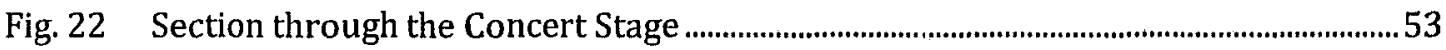

Fig. 23 Perspective View of the Concert Stage ............................................................................54 
Fig. 24 Perspective View of the Residences ............................................................................54

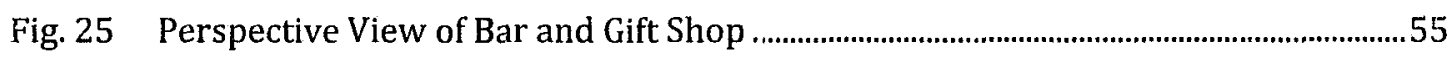

Fig. 26 Perspective View of a Concert..........................................................................................55

Fig. 27 Perspective View from Audience Platform in a Concert ...................................................56

Fig. 28 Perspective View above Sound Control Booth in a Concert ............................................56

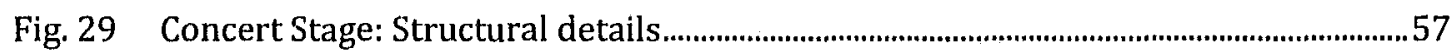

Fig. 30 Concert Stage: Structural details from a side view .........................................................57

Fig. 31 Elevation of a Sleeper Car and a Canvas Car .....................................................................58

Fig. 32 Isometric of a Sleeper Car and a Canvas Car ....................................................................58

Fig. 33 Sleeper Car in Motion: Communal Space for Jam Sessions ..............................................59

Fig. 34 Sleeper Car in Motion: Beds Unfolded for Sleeping ............................................................59

Fig. 35 Sleeper Car Stopping in a Small Town: Converted into Small Concert Stage ............60

Fig. 36 Sleeper Car Stopping at the Festival Sites: Assembled as a Communal Residence.60

Fig. 37 Sleeper Car: Deployment into a Temporary Residence......................................................61

Fig. 38 Canvas Car: Deployment into a platform ...........................................................................62

Fig. 39 Canvas Car: Deployment into a platform .............................................................................62

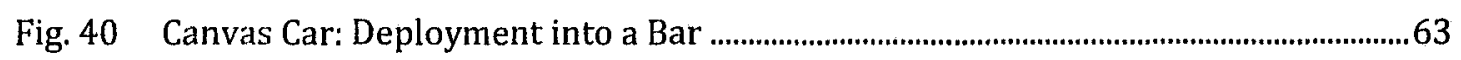

Fig. 41 Can vas Car: Deployment into a Gift Shop ..................................................................63

Fig. 42 Structural Components of a Sleeper Car: in the Residence Mode ..................................64

Fig. 43 Structural Components of a Canvas Car: in the Platform Mode..........................................64

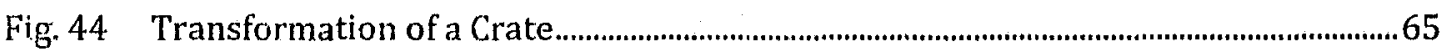

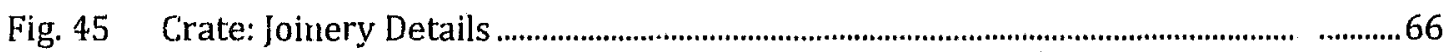

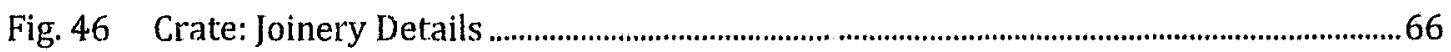




\section{Introduction}

"Canada must now preserve its identity by having many identities." 1

-Northrop Frye

In the early years of the formation of Canada, territorial integrity was conserved and protected by its transcontinental railway network. By providing passenger services and the transportation of agricultural products and raw-materials, railroads allowed both nature and human resources to be distributed to different parts of Canada. Political boundaries were defined by railway networks. However, cultural integrity was far beyond what physical infrastructures could pull together.

In his book, The Defiant Imagination, Why Culture Matters, art critic, Max Wyman believes the cultural integrity of a nation is based on recognizing, sharing and understanding cultural variations, so citizens are less fragmented and divided. ${ }^{2}$ The question is how do we understand a culture? Well-known anthropologist, Clifford Geertz argues that to understand a culture, we need to have a "semiotic approach" 3 to gain access to the conceptual world of that specific culture. He also suggests that "a good interpretation of anything - a poem, a person, a history, a ritual, an institution, a sociaty - takes us into the heart of that of which it is the interpretation." 4 Music can be considered as an interpreted form of cultural expression. This is similar to Simon Frith's description of African music as "a cultural

\footnotetext{
${ }^{1}$ Frye, Northrop, Robert D. Denham, David Staines, and Jean O'Grady. Northrop Frye on Canada. (Toronto: University of Toronto Press), 2003.

2 Wyman, Max. The Defiant Imagination: Why Culture Matters. (Vancouver: Douglas \& McIntyre l,td., 2004 ), 81.

3 Clifford, Geertz. The Interpretation of Cultures: Selected Essays by Clifford Geert. (New York: A Member of the Perseus Books Group, 1973), 24.

${ }^{4}$ Ibid, 18.
} 
activity which reveals a group of people organizing and involving themselves with their own communal relationships"5 in the book, Performing Rites: on the Value of Popular Music.

This thesis is entitled 'Music Tracks' with: music tracks as railway tracks contributing for cross-country music performances; music tracks as audio tracks in $\mathrm{CD}$ albums; and, music tracks as the collective memories of a people ${ }^{6}$. Using the analogy of audio tracks in CD albums, this thesis has ten 'tracks'. These tracks are grouped into three parts: 'Do', 'Re', and 'Me'. 'Do' introduces the background by describing the evolution of Canada's multicultural society. 'Re' will first discuss the conservation of a cultural diversity as the construction of the national identity through various music events. Secondly, 'Re' will describe the conventions of cross-country music tours and the precedents of mobile architecture. 'Me' will document the design portion for this thesis - the proposal for an annual music festival staged in both the east and the west regions of Canada.

${ }^{5}$ Frith, Simon. Performing Rites: on the Value of Popular Music (Cambridge, Massachusetts: Harvard Unviersity Press, 1996), 272.

${ }^{6}$ Halbwachs, Maurice. On Collective Memory. (Chicago: Univeristy of Chicago Press, 1992), 40. 


\section{- Da -}

\section{Track 1: The Beginning}

"When first I did appear upon this native soil All up and down this country at labor I did toil I slumbered in the moonlight and I rose with the sun I rambled through the canyons where the cold rivers run When first I did come down where the land meets the sea The people said Who are you and what would your name be I said I have no home and I am no man's son 'Twas inland I was born and from inland that I come

In the good land I was young and I was strong No one dared to call me son Happy just to see my day's work done See my day's work done."

$\sim$ Crossroads, THE WAY I FEEL, by GORDON LIGHTFOOT

Driven by a dream for better living, European settlers sailed across the Atlantic Ocean and arrived at the land which is now called Canada. Irish, Italian, Portuguese, and Dutch various European cultures and traditions were seeded on the east ccast of the North American continent. Sea navigation bridged the European coasts and the New World, the construction of railway networks made the dry lands traversable and connected the Pacific and Atlantic coasts. 
The political boundaries of Canada were defined in 1867 by the formation of a confederation: the Dominion of Canada (Fig. 1). At that time, access to the west regions of the Dominion was only made by canoe or on horseback. Competitively, the United States was developing its western frontiers about the same time. The Canadian government had a great fear that the west regions might become the annexation of the U.S. The Dominion of Canada looked at ways to draw the north-west region of North America into the Canadian confederation. In 1871 , British Columbia requested a transportation link as a condition to join the confederation. Instead of a wagon trail originally requested by British Columbia, the Canadian government promised to build a transcontinental railway within ten years to link the western provinces to the eastern provinces. ${ }^{7}$

After the completion of the railway, raw-materials like timbers and minerals were provided with a better transportation system (with larger capacity but within a shorter time period) to the manufactures in the eastern provinces. Labourers and professionals had easier access to different parts of Canada. Within the political boundaries of Canada, both human and natural resources were shared as a whole. In this way, railroads secured the Canadian territorial integrity. "Hereafter, the history of this railway becomes the tale of the evolvement of this country into a nation of world status."8

7 Salloum, Habee. "Canada's Railroads." Contemporary Review 281, December (2002): 361

8 Ibid. 360 


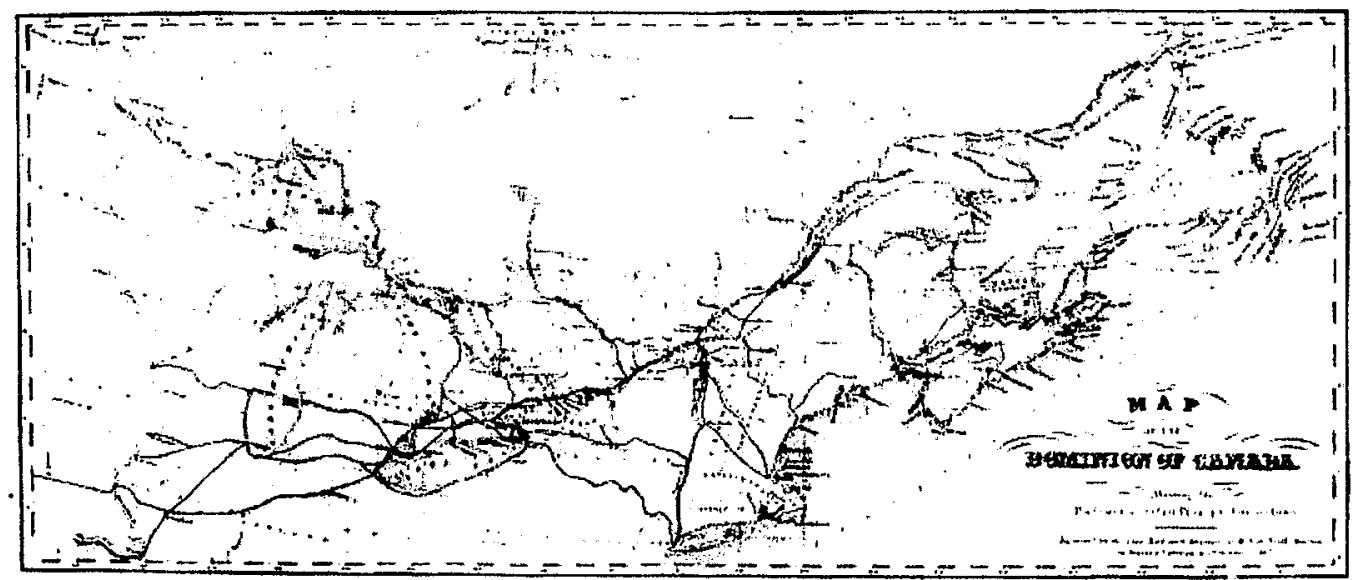

Fig. 1 Dominion of Canada, 1867, the Railways and their principal connections

Source: Statistics Canada, Canada Year Book, 1917.

http://www65.statcan.ca/acyb04/18xx/acyb04_18690013-eng.htm 


\section{Track 2: Gateway to Prairie Towns}

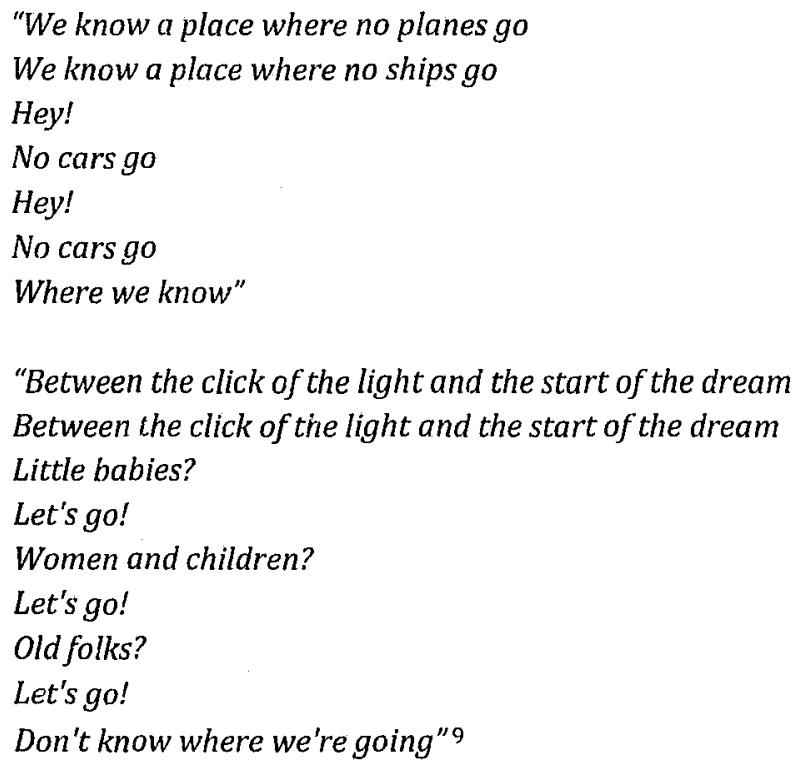

$\sim$ No Cars Go lyrics from album, Neon Bible, by Arcade Fire

For many European immigrants the settlements in the east coast of Canada were not their final destination; these immigrants continued to travel by train to the western regions for less-expensive lands. (Fig. 2) As a result, settlements with various cultural backgrounds sprawled from the train stations and further evolved into small towns. For many prairie towns, train stations acted as town centres. "During the boom years before the First World War, three national railways extended their tentacles across the largely unpopulated prairies, first choosing locations for their stations and then building the communities

\footnotetext{
${ }^{9}$ No Cars Go. http://www.lyricstime.com/arcade-fire-no-cars-go-lyrics.html (accessed 05 2009).
} 
around them."10 For many new-born towns, the railway was the only access to them. Train stations not only became gateways to those communities scattered in the prairies, but also granted access to those diverse regional-cultures.

Other than the physical functionality of passenger service and freight transportations, the train stations also acted as information outlets. Prior to the wide-spread use of telephone and radio, train stations were the place where town residents came to send and receive telegraphs and mail. News about the First World War, elections, and sports were announced and released at train stations. Train stations literally became the cultural centers of many communities. ${ }^{11}$

10 Brown, Ron. Train Doesn't Stop Here Anymore: An Illustrated History of Railway Stations in Canada. 3rd. (Toronto: Dundurn Press, 2008), 33

11 Brown, Ron. Train Doesn't Stop Here Anymore: An lllustrated History of Railway Stations in Canada. 3rd . (Toronto: Dundurn Press, 2008), 138. 


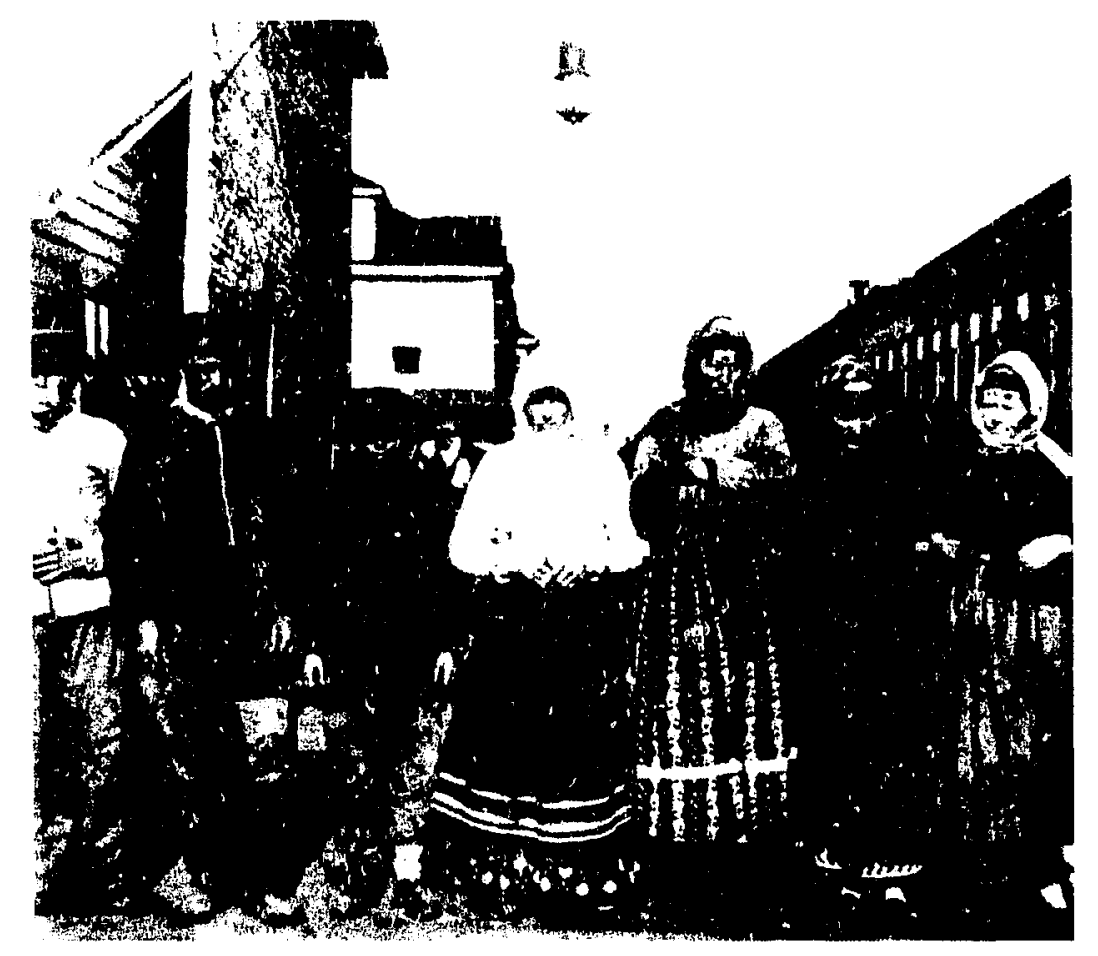

Fig. 2 European Farmers: at CPR Station in Winnipeg

Brown, Ron. Train Doesn't Stop Here Anymore: An llilustrated History of Railway Stations in Canada. 3rd. (Toronto: Dundurn Press, 2008), 137. 


\section{Track 3: A Collage of Faces}

"Just before our love got lost you said,

'I am as constant as a northern star.'

And I said, 'Constantly in the darkness.

Where's that at? If you want me I'll be in the bar.'

On the back of a cartoon coaster

In the blue TV screen light

I drew a map of Canada, oh Canada

With your face sketched on it twice

Oh, you are in my blood like holy wine

You taste so bitter and you taste so sweet

oh, I could drink a case of you, darling

And I'd still be on my feet

I'd still be on my feet"12

$\sim$ A Case of You, LIVE IN PARIS,

bY DIANA KRALL

In the past two centuries, Europeans, as the majority of the Canadian population, carried on their own traditions, social structures and political systems in Canada. Adopted from British political traditions, the Canadian parliament remains one of the most important political systems established to allow regional voices (different political opinions) to be heard in the central government.

The retirement of the Baby Boom Generation will very soon reach its climax in the year of 2015, which means that there will soon not be enough domestic talents to sustain the steady growth of the Canadian economy. The federal government will need to look abroad for skilled individuals to fill these vacancies ${ }^{13}$. In the last twenty-five years of the twentieth

\footnotetext{
12 Written by Joni Mitchell. Partially qquoted from A Case of You lyrics from alum, live in Paris.

${ }^{13}$ Wyman, Max. The Defiant Imagination: Why Culture Matters. (Vancouver: Douglas \& Mclntyre Ltd., 2004), 76
} 
century, there have already been more immigrants who have arrived in Canada from nonEuropean regions than ever before. ${ }^{14}$ According to census polls and projections, there will be an increase in the population of non-European immigrants: from ten-percent in 1991 to a projected twenty-percent in $2016 .{ }^{15}$ According to the projected tendency, there will be non-European culture influences continually brought into Canada. Their foreign influences will be implanted into Canada within the already-established political framework.

In response to this change, Governor General, Adrienne Clarkson made a statement in her speech: "Canada is defined by far more than its political boundaries or economic relationships. In these times of rapid change and globalization, it is more important than ever that we know who we are as Canadians and what brings us together." 16

Although "Immigration was bringing permanent change to the face of Canada," 17 and Canada is now inhabited by immigrants from various ethnic backgrounds, it is believed that Canadian identity is based on neither unifying nor merging of different cultural groups within the national borders of Canada. Instead, Canadian identity is based on the tolerance of other's cultural expressions; at the same time, it is established by respecting other cultures by recognizing, sharing, and collaborating. Max Wyman has a similar argument, and claims that Canada is "a unified society built on recognition of the fundamental integrity of parallel ethnicities and beliefs." $18 \mathrm{He}$ also believes that "Pluralism and cooperation are the foundation on which Canada was built and the core of its social strength today." 19 Wyman

\footnotetext{
14 Wyman, Max. The Defiant Imagination: Why Culture Matters. (Vancouver: Douglas \& McIntyre Ltd., 2004), 76. 15 lbid., 76.

${ }^{16}$ Quoted from Speech from the Throne, January 2001 by Adrienne Clarkson. 3rd Session, Speech from the Throne. 2004. http://www2.parl.gc.ca/parlinfo/Documents/ThroneSpeech/37-1-e.html (accessed April 2009).

17 Wyman, Max. The Defiant Imagination: Why Culture Matters. (Vancouver: Douglas \& McIntyre Ltd., 2004), 76.

18 Ibid., 77.

${ }^{19} \mathrm{lbid}$.
} 
suggests Canadian painter, Lewis Lavoie, expresses a similar ideology of protecting pluralism with common grounds in his mural mosaic, titled Adam - One Blood, Many Nations (Fig. 3). He composed a portrait of Adam (referring to Michelangelo's fresco painting, The Creation of Adam $^{20}$ ) with twenty smaller portraits of different races dressed in their own traditional costume. His work can be interpreted as an ideal harmony of the global village which is achieved by muitiple ethnicities. If we think a face is an identity of a serson, the face of Canadian society', very close to Lavoie's depiction, is like a collage of many 'ethnic faces.'

20 Fresco on the ceiling of the Sistine Chapel, The Sistine Chapel. http://mv.vatican.va/3_EN/pages/CSN/CSN_Main.html. 


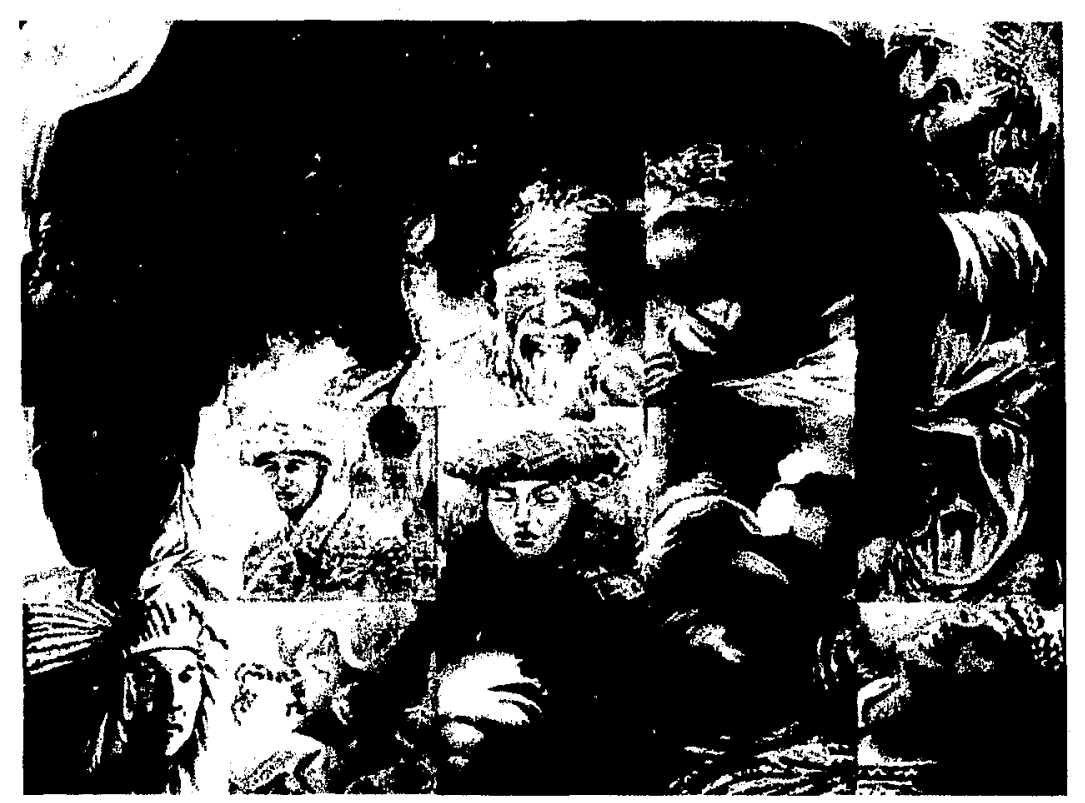

Fig. 3 Adam - One Blood, Many nations: Painted by Lewis Lavoie

http://3.bp.blogspot.com/_nlB2iavXqvs/ScvP3hATkdl/AAAAAAAADQk/tfsBm_-bEy8/s1600h/ADAM+-+One+Blood,+Many+Nations+Painting.jpg 


\section{- $\mathscr{R e}$ -}

\section{Track 4: The Heartbeat of a People}

\footnotetext{
"Music can be seen as an abstract representation of social organization, as the geometry of social structure."21

$\sim$ Simon Frith
}

As elucidated in 'Track 3,' Canadian society consists of multiple ethnic groups. Especially, during the last twenty-five years of the twentieth century, there have been many nonEuropean immigrants rooted in Canada, 22 Music is the heartbeat of those people and it has tracked their collective memories from their mother lands. Some of them were professional musicians of their traditional music. Middle-Eastern folk dance and classical traditions have been brought by the Syrians, Lebanese, Palestinian and Egyptians. Caribbean immigrants brought calypso, steel band, soca, reggae, ska, dub poetry, rap and hip hop. African immigrants from countries such as Somalia, Ghana, Nigeria, Ethiopia, Eritrea, Mali, Senegal, Zaire, Cameroon, Guinea-Bissau, and South Africa have performed both traditional and more contemporary music such as Ghanaian "high-life," soukous, or mbaquanga. They also joined fusion ensembles ${ }^{23}$.

\footnotetext{
${ }^{21}$ Frith, Simon. Performing Rits: on the Value of Popular Music (Cambridge, Massachusetts: Harvard Unviersity Press, 1996), 270.

22 Ibid., 315.

${ }^{23}$ Keillor, Elaine. Music in Canada (Quebec: McGill-Queen's Unviersity Press, 2006), 315
} 
Music is one of the most powerful art forms which reflects cultural values in Canadian society. Music represents a people's lifestyle and their cultural activities. Those cultural activities have evolved from their surrounding environments. In this way, music is articulated with space yet is beyond space itself: music tracks collective memories and perceptions beyond any geographical limitation. "Whether jazz or rap for AfricanAmericans or nineteenth-century chamber music for German jews in Israel, [music] both articulates and offers the immediate experience of collective identity." 24

"All the heady mixtures we can hear at popular music festivals across the land - is one of the clearest demonstrations of the power that cultural cross-inspiration can have on how we express ourselves. In this world of creativity and imagination, we can find new structures of inclusion, new understandings of the other, new ways to access the tools that will allow everyone to take part. In that regard, as well as many others, the arts and culture are inextricably intertwined with all the other aspects of our lives. ${ }^{25}$

Ethnic musical influences have varied in different regions of Canada. The geographical locations of those ethnic in luences usually depend on the travel distances to their home countries. For example, Britis` Columbia has been influenced by the Asian cultures from across the Pacific Ocean. Jazz butoh has been influenced by Vancouver's Kokoro Dance which is founded by French-Canadian, Barbara Bourget and Japanese-Canadian, Jay Hirabayashi. ${ }^{26}$ Taiko Drumming is played among the Japanese communities. ${ }^{27}$ The eastern provinces were influenced by European music traditions. Aside from Portuguese guitar, Fado music was played among large Portuguese communities in Toronto and Montreal.

\footnotetext{
${ }^{24}$ Frith, Simon. Performing Rits: on the Value of Popular Music (Cambridge, Massachusetts: Harvard Unviersity Press, 1996), 273.

25 Wyman, Max. The Defiant Imagination: Why Culture Matters (Vancouver: Douglas \& McIntyre Ltd.), 2004.

${ }^{26}$ A butoh dance company based in Vancouver, British Columbia, found in 1986. Barbara Bourget and Jay Hirabayashi. http://www.kokoro.ca/biographies/jay_and_barbara.htm (accessed 04 2009).

27 Uzume Taiko. http://www.uzume.com/ (accessed 03 2009).
} 
Brought to Canada by Scottish immigrants across the Atlantic Ocean during the Highland Clearance, the traditional style of fiddle music was preserved in Cape Breton Island. Music is influenced by the surrounding environment but the influences of music lie beyond political borders.

\section{Track 5: The Blood Vessels of a Land}

"There was a time in this fair land when the railroad did not run

When the wild majestic mountains stood alone against the sun

Long before the white man and long before the wheel

When the green dark forest was too silent to be real

But time has no beginnings and hist'ry has no bounds

As to this verdant country they came from all around

They sailed upon her waterways and they walked the forests tall

And they built the mines the mills and the factories for the good of us all

For they looked in the future and what did they see

They saw an iron road runnin' from sea to the sea

Bringin' the goods to a young growin' land

All up through the seaports and into their hands

Look away said they across this mighty land

From the eastern shore to the western strand

Bring in the workers and bring up the rails

We gotta lay down the tracks and tear up the trails

Open 'er heart let the life blood flow

Gotta get on our way 'cause we're movin' too slow

Bring in the workers and bring up the rails

We're gonna lay down the tracks and tear up the trails

Open 'er heart let the life blood flow

Gotta get on our way 'cause we're movin' too slow

Get on our way 'cause we're movin' too slow

Canadian Railroad Trilogy, SUNDAY CONCERT,

bY GORDON LIGHTFOOT 
In the pre-highway era, it was difficult to travel from town to town in northern Ontario and Quebec. During that time, communities were isolated from each other by swamps and swirling rivers. The railways were the lifeline and the only contact with the outside for the town citizens. ${ }^{28}$ Other than a symbolic framework of Canada's political integrity, as described in 'Track 1,' railroads were also as important as blood vessels of a human body by providing resources for regional needs (Fig. 4). During the time when small towns lacked medical services and the railroads were the only access to them, the Ontario department of Health created rolling dentists' offices. A dental car rolled on tracks from town to town to provide dental service.

Trains also functioned as show cases from town to town for promotion purposes. In his book, The Train Doesn't Stop Here Anymore, Ron Brown describes how "in 1913 a 'Made in Canada' train toured the stations of the CPR [Canadian Pacific Rail]. Canadians flocked to their stations to see the variety of products then made in Canada."29

For educational purposes, there were trains converted into moving class rooms. The Saskatchewan College of Agriculture sent out "Better Farming" 30 trains carrying exhibits of livestock, field crops and farm machinery to many stations in the rural areas of Saskatchewan every June and July from 1915 to 1918 . As documented by Ron Brown, in 1922, North Bay Ontario school inspector, J.B. McDougall, convinced the Department of

\footnotetext{
${ }^{28}$ Brown, Ron. Train Doesn't Stop Here Anymore; An Illustrated History of Railway Stations in Canada. 3rd. (Toronto: Dundurn Press, 2008), 143

${ }^{29}$ Ibid., 141

${ }^{30}$ Ibid., 141
} 
Education to launch an experimental project with a rolling schoolroom equipped with desks, books, backboards, and living quarters for a teacher and his or her family. (Fig. 5)

"They would travel back and forth along a predetermined stretch of railway line and spend a week on the sidings of the smallest communities. From the native communities, the trappers' shacks, and the railway workers' homes nearby, the children would emerge, books and homework in hand, ready for another week of lessons. ${ }^{31}$

Nicknamed the "Weed Train,"32 another travelling classroom was designated for crop displays and farming seminars. Like a frame structure holding a building together, railway tracks maintained Canada's territorial integrity in the era of the steam train. Like blood vessels transporting oxygen and nutrients throughout the human body, railroads populated the empty land with cultural activities. Through railway networks, resources were shared across the country and regional cultures evolved together as one nation.

${ }^{31}$ Ibid., 143

${ }^{32}$ Ibid., 141 


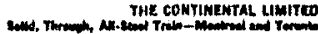

To THE HaUnT of CAPTalk KIDD

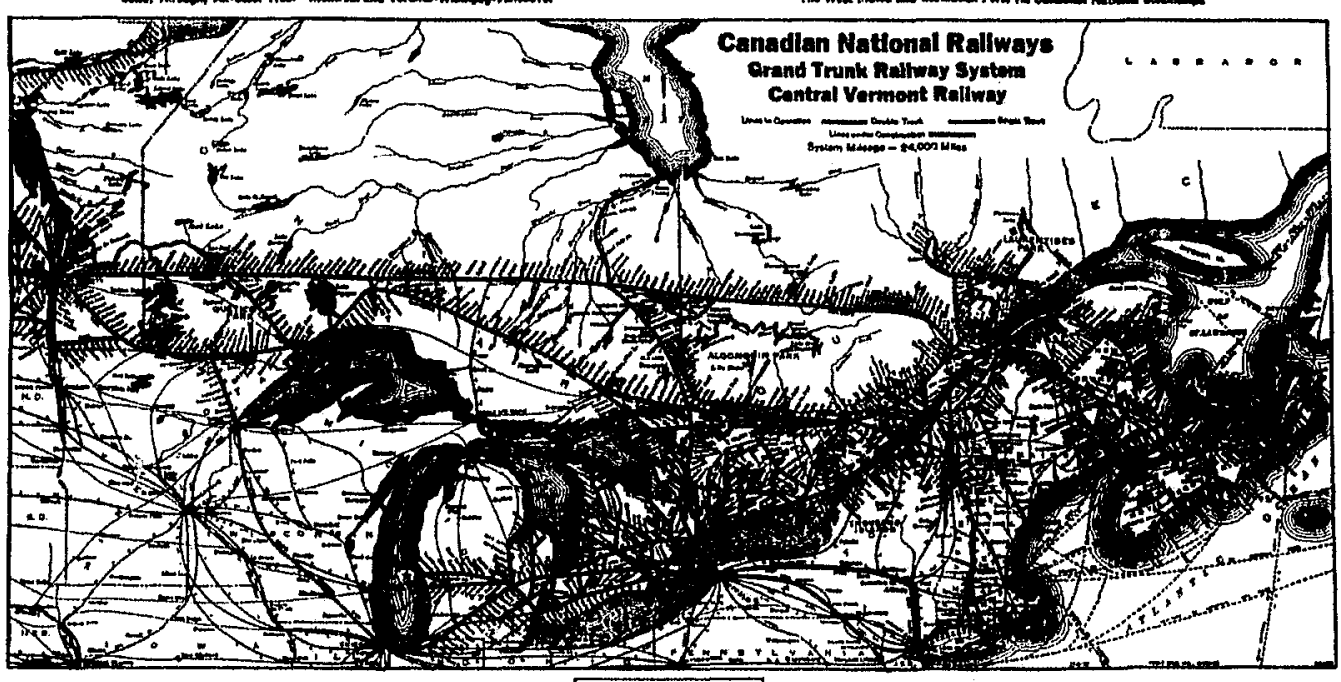

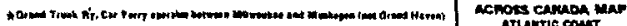

TAAVEL EY TRAIM

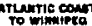
ine Ratiway to twe wate way

Fig. 4 Canadian National Railways route map

http://www.nps.gov/history/history/online_books/steamtown/shs3.jpg

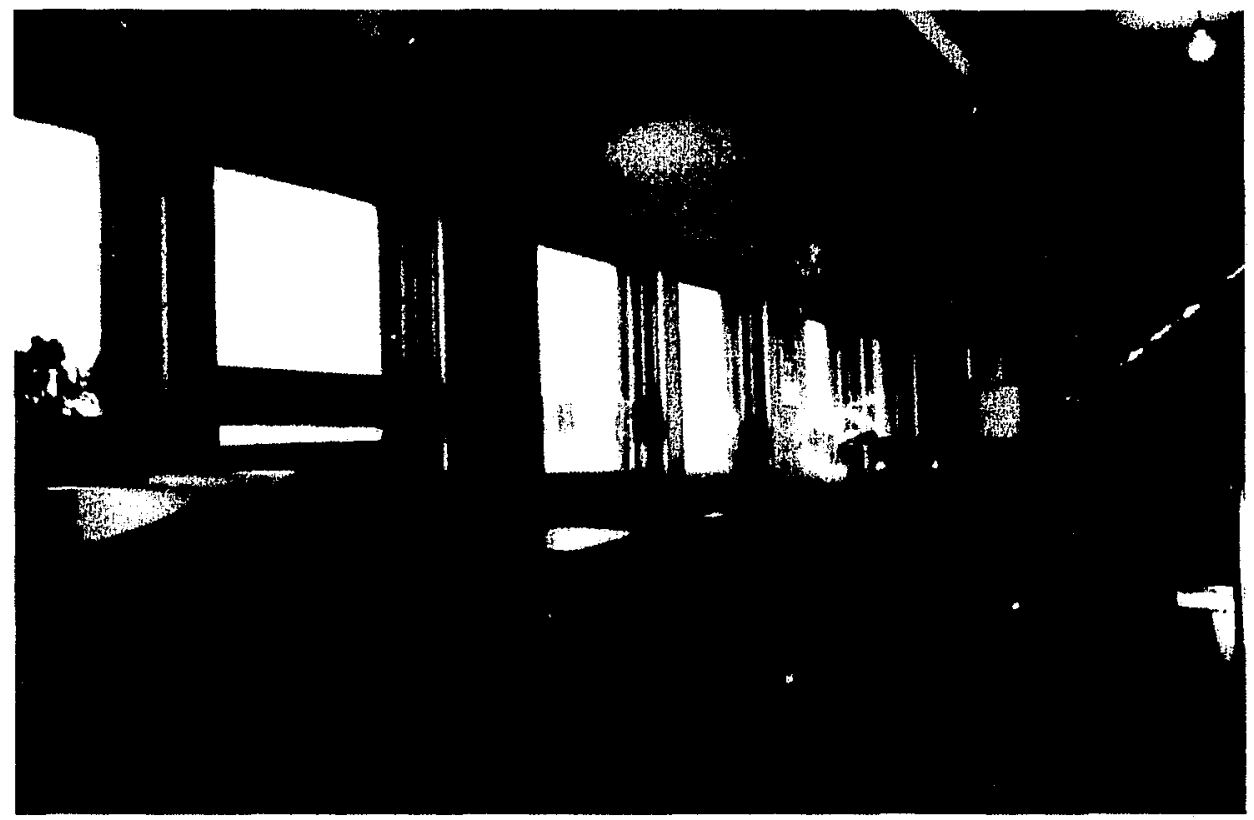

Fig. 5 Classroom on Wheel

Brown, Ron. Train Doesn't Stop Here Anymore: An Illustrated History of Railway Stations in Canada. 3rd. (Toronto: Dundurn Press, 2008), 144. 


\title{
Track 6: The Fall of the Railway Empire
}

\author{
"Train train rolling round the bend \\ Train train rolling round the bend \\ Well it took my baby \\ Away from me again \\ Come down to the station \\ Meet my baby at the gate \\ Asked the station master \\ If the train's running late \\ He said "If you're a-waiting \\ on the 444 \\ I hate to tell you son \\ That train don't stop here anymore ${ }^{\prime 33}$
}

Mystery Train, MOONDOG MATINEE,

by THE BAND

The first half of the twentieth century witnessed the fall of the Canadian railway. The rise of automobiles, highways, and airlines broke the monopoly the railway had in passenger services. "In 1893 Canadians saw their first car. In 1908 Henry Ford opened his Model T assembly line and within ten years 200,000 cars were chugging and sputtering along Canada's muddy roads." ${ }^{34}$ (Fig. 6) With an innovative production technique of a "constantlymoving assembly line; subdivision of labour, and careful coordination of operations,"35 Ford's manufacturing made a significant improvement on its productivity: a complete chassis was produced every 93 minutes. The price of a Model T was dropped from $\$ 950$ to

${ }^{33}$ Written by S. Phillips and H. Parker. Album: Moondog Matinee. Mystery Train. http://theband.hiof.no/lyrics/mystery_train.html (accessed 05 2009).

${ }^{34}$ Brown, Ron. Train Doesn't Stop Here Anymore: An Illustrated History of Railway Stations in Canada. 3rd. (Toronto: Dundurn Press, 2008), 157

35 Bellis, Mary. Henry Ford (1863-1947). http://inventors.about.com/od/fstartinventors/a/HenryFord.htm (accessed 042009). 
$\$ 280$ in American dollars from 1908 to 1927 . Henry Ford achieved his goal to "build a car for the great multitude." 36 Automobiles were no longer luxury items. Instead, they became essential for daily transportation; North American society was turned into the age of the motor. Even though, without highways, automobiles still has no competition against trains. Brown gives an example of this in his book. He stated that it took about eleven hours to travel from Toronto to the town of Walkerton by driving on "narrow dirt roads." ${ }^{37}$ Train rides would take less than four hours to complete the same trip.

As urbanization patterns were altered by the increasing population of automobile owners, Canadian highways were constructed to provide interurban travel after the First World War. The government spent $\$ 93$ million on highway construction. Ironically, the tax paid by railway companies was spent on highway constructions which benefited their own competitors such as express buses and trucks. From 1920 to 1930 more than a million cars were traveling on Canadian highways. The Canadian government began to shift their focus from railway networks to highway infrastructures.

In response to the development of new transportation technology (highways and automobiles) and the alteration of urbanization patterns, the Canadian federal government passed the Trans-Canada Highway Act in the year of 1949.38 The intent was to build a national highway system which connects highways in the western and eastern provinces.

\footnotetext{
36 Bellis, Mary. Henry Ford (1863-1947). http://inventors.about.com/od/fstartinventors/a/HenryFord.htm (accessed 04 2009).

37 Brown, Ron. Train Doesn't Stop Here Anymore: An Illustrated History of Railway Stations in Canada. 3rd. (Toronto: Dundurn Press, 2008), 157.

38 Ibid.
} 
The construction of the Trans-Canada Highway was completed in 1962 . By the 1960s, 1.25 million had already been spent on highways by the Canadian government. ${ }^{39}$

Other than highways, Trans-Canada Airlines were another government-supported infrastructure created by C.D. Howe in 1936. The creation of Canadian Pacific Airlines followed in 1942. Traveling from the Atlantic coast to the Pacific coast was dramatically reduced from five days by train ride to four hours by flight. Public preference was increasing towards "private automobile for shorter trips and jet aircraft for longer tips." 40 Freight services remained mainly for agricultural and industrial products such as cattle, crops, timbers, and minerals.

Passenger train traffic dramatically declined after the Second World War, downgrading and demolishing became the common fate of many Canadian train stations on branch lines. For the commuter line between Toronto and Peterborough, the CPR (Canadian Pacific Rail) demolished every station between 1978 and 1983. Forward, Saskatchewan was once a busy farm town with both CNR (Canadian National Railway) and CPR railway lines running through it. When drought and the depression struck Forward in the 1930s, the train station was down-graded. In 1962, the train station was completely removed. Today, the site is an empty field with railway roadbed which is barely seen. ${ }^{41}$ Several stations across Canada were saved but converted for other various purposes such as museums, farmer's markets, and restaurants. The Smith Falls Rail Museum and Elgin County Railway Museum are examples of this. "Canadians began living farther and farther from the stations. Within a few

\footnotetext{
39 Ibid.

40 Brown, Ron. Train Doesn't Stop Here Anymore: An llustrated History of Railway Stations in Canada. 3rd. (Toronto: Dundurn Fress, 2008), 158.

41 Ibid., 162.
} 
short years, stations had gone from being the heart and focus of the community to another forgotten deteriorating building." 42 In 1945 , the number of passengers carried by trains had reached its climax of 55.4 million. This number dropped significantly to 27.2 million by the mid 1950s with nearly all branch line passenger service ending by 1970 . By the year of 1990 there were barely 6 million passengers. ${ }^{43}$ Today, aside from a limited passenger services, the primary function of Canadian railroads is for freight transportation. Railroads no longer contribute to bringing various ethnic groups to different regions of Canada on a large scale.

\footnotetext{
42 Ibid., 157.

43 Brown, Ron. Train Doesn't Stop Here Anymore: An Illustrated History of Railway Stations in Canada. 3rd. (Toronto: Dundurn Press, 2008), 159.
} 


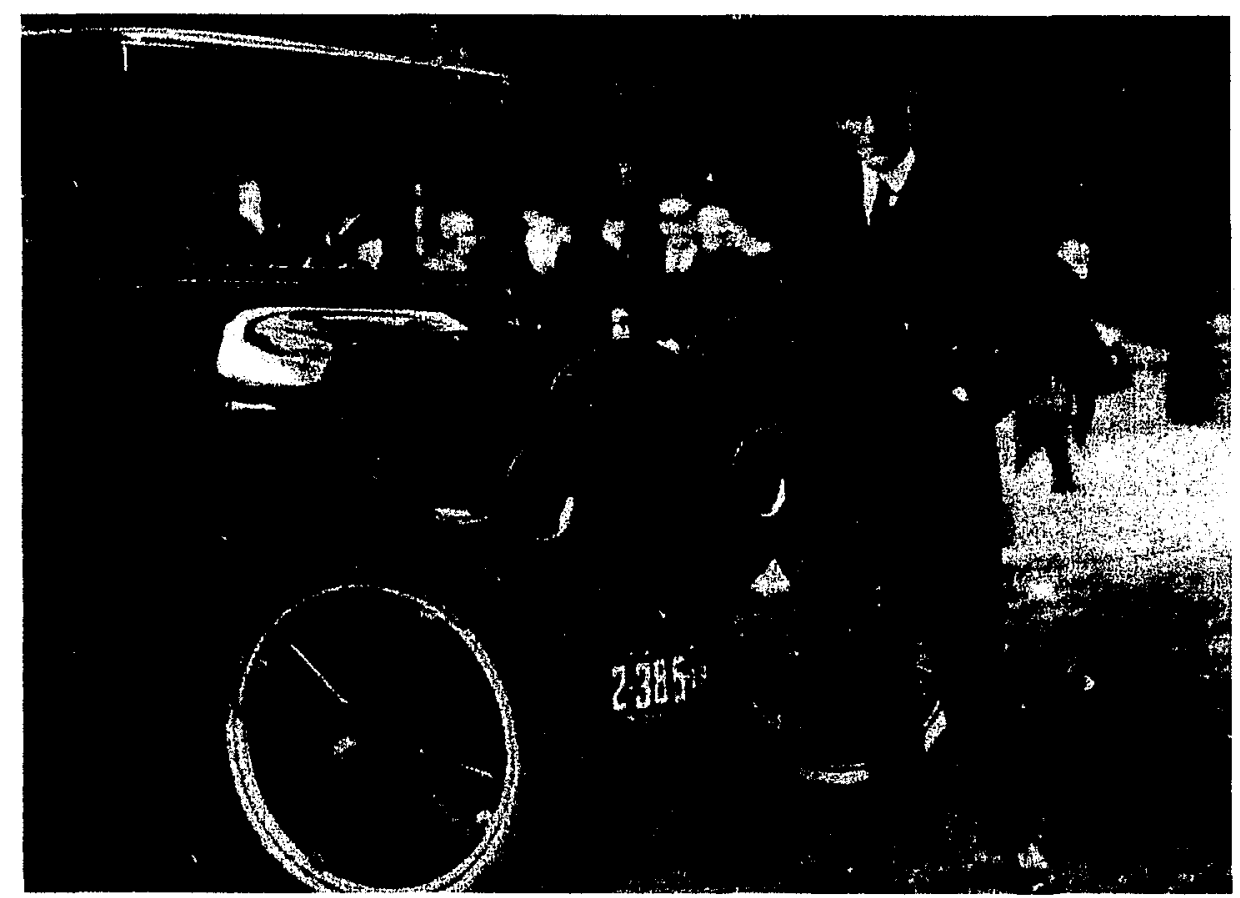

\section{Fig. 6 Henry Ford and His Model-T}

http://www.shadetreemechanic.com/images/Ford\%20Henry\%20Ford\% 20Model\%20T.ing 


\section{Track 7: Diversity within an Integrity}

"Canada's cultural integrity will be a key issue confronting the nation in the coming decade. Faced with the threat of international cultural uniformity, we must affirm the diversity of our cultural expression, the uniqueness of the threads that make up our pluralistic nation. A strong, healthy cultural community, one that embraces all the possibilities the new knowledge economy can offer, is vital to the continued evolution of the Canadian identity." $" 4$

$\sim$ Max Wyman

A cultural mosaic 45 is an analogy often used to describe the mix of ethnic groups and cultures within the Canadian identity; it makes Canada distinctive from other countries. Max Wyman argues that "under the levelling influence of globalization, a nation's cultural heartbeat becomes its source of pride and identity, and an international agreement on the unique importance of cultural diversity can help ensure that nation's cultural expression is giving its own space in which to grow." 46 It is believed that the protection of diversity does not necessarily cause the absence of integrity. To find common ground across cultures requires "recognizing, sharing and understanding our cultural variations," in this way, "we are less fragmented and divided" 47 This leads to the crucial question: how do we recognize, share and understand cultural variations?

\footnotetext{
44 Wyman, Max. The Defiant Imagination: Why Culture Matters (Vancouver: Douglas \& McIntyre Ltd., 2004 ), 8.

${ }^{45}$ Statistics Canada. Canada's ethnocultural portrait: The changing mosaic. http://www12.statcan.ca/english/census01/products/analytic/companion/etoimm/canada.cfm (accessed 0429,2009 ).

46 Wyman, Max. The Defiant Imagination: Why Culture Matters (Vancouver: Douglas \& McIntyre Ltd., 2004 ), 81.

${ }^{47}$ Ibid., 83.
} 


\section{Culture is....}

Anthropologist, Clifford Geertz opposes the methodology which considers culture as a mental phenomenon which can be "analyzed by formal methods similar to those of mathematics and logic." 48 Instead to study culture, he proposes the methodology of Thick Description $^{49}$ in The Interpretation of Cultures: Selected Essays by Clifford Geertz. Geertz uses the example of a wink to differentiate Thick Description from Thin Description of human behavior. A wink contains several levels of meaning and can be interpretated as either a twitch, a conspirial code, a parody, or a satire. Thick Descripiton explains the context behind a human behaviour, but Thin Description merely depicts the practice of a wink..$^{50}$ Geertz further argues that a semiotic approach is the access to the conceptual world of a culture.51 In this case, the interpretation of a wink is the semiotic approach which leads to multiple levels of meaning behind the wink itself. Geertz believes "a good interpretation of anything - a poem, a person, a history, a ritual, an institution, a society - takes us into the heart of that of which it is the interpretation." 52 To understand another culture, empathy is required to position ourselves in the perception of that cultural group through art forms as a medium.

${ }^{48}$ Clifford Geertz. The Interpretation of Cultures: Selected Essays by Clifford Geertz (New York: A Member of the Perseus Books Group, 1973), 12.

${ }^{49}$ Geertz adopted the term form philosopher, Gilbert Ryle. Clifford, Geertz. The Interpretation of Cultures: Selected Essays by Clifford Geertz (New York: A Member of the Perseus Books Group, 1973), 6.

${ }^{50}$ Clifford Geertz. The Interpretation of Cultures: Selected Essays by Clifford Geertz (New York: A Member of the Perseus Books Group, 1973), 7.

51 Ibid., 24.

52 Ibid, 18. 


\section{Music performance as Semiotic Approach}

Based on Clifford Geertz' argument of a semiotic approach and Max Wyman's ideology of a society of pluralism, this thesis proposes that Canadian cultural variety must not be comprehended by intellectual analyses or verbal descriptions; instead, it must be experienced through a conceptual approach such as music performances.

In response to the discussions in 'Track 4,' (various music activities take place in different regions of Canada), music performances represent regional cultures in different forms. Musical instruments, use of language, literature, and religious backgrounds are elements of cultural expressions. Theo van Leeuwen thinks "music could be seen as an abstract representation of social organization, as the geometry of social structure." 53 Marxist and Weberian musicologists have similar arguments; they think "music is a form of ideological expression, not just in broad institutional terms (how it is played and heard)." 54 From those aspects, experiencing music as a semiotic approach is essential to understand and to recognize a culture.

53 Frith, Simon. Performing Rits: on the Value of Popular Music (Cambridge, Massachusetts: Harvard Unviersity Press, 1996), 270.

54 lbid., 269. 


\section{Interaction between music and cultures}

Theo van Leeuwen also reminds us that music is produced by cultures; at the same time, it shapes cultures. The interaction between music and cultures is a cyclical cause and consequence; music influences culture, and is influenced by culture simultaneously. Theo van Leeuwen claims that "Music not only represents social relations, it also and simultaneously enacts them" 55 Simon Frith has a similar argument in his book, Performing Rites: on the value of popular music. "The question is not how a piece of music, a text, [reflects] popular values, but how -in performance - it produces them." 56 Based on both van Leeuwen and Frith's claims, this thesis further proposes that Canadian society must provide a 'national stage' for regional music, similar to the current parliament system, which allows diverse cultural expressions from different social groups to be heard by larger populations. In addition, the 'national stage' must have flexibilities, similar to music tours, to deliver performances to different regions across Canada as a means to reach out to local communities.

\footnotetext{
55 Frith, Simon. Performing Rits: on the Value of Popular Music (Cambridge, Massachusetts: Harvard Unviersity Press, 1996), 270.

56 Ibid.
} 


\title{
Track 8: A Western Odyssey
}

\author{
"And I'd rather be \\ walking through the tall pine trees \\ high \\ up above Lake Louise \\ And I'd rather be \\ chasing after shooting stars \\ than waiting for this dumb 503 TTC \\ I'd like to see \\ the sun set behind Saddle Mountain \\ and listen to the wind whisper my name \\ yeu this world and me don't fit \\ one of us is going to have to quit \\ oh how I mizs those western skies \\ And I'd rather be \\ back in the Rocky Mountains \\ than sitting in some bar on Queen Street \\ And I'd rather be \\ walking through the high meadow \\ than watching the latest war on my TV \\ So please don't you stand in my way \\ I just got to get out of this place \\ if I waste another day \\ I'm sure the sun will forget my name \\ Oh how I miss those western skies"57
}

Western Skies, LOST TOGETHER, by BLUE RODEO

\footnotetext{
57 Written by Jim Cuddy, Greg Keelor. Partially quoted from Western Skies lyrics from album, Lost Together.1992. Blue Rodeo: Western Skies Lyrics. http://www.metrolyrics.com/western-skies-lyrics-blue-rodeo.html (accessed 05 2009).
} 


\section{Mobile Architecture}

Following the argument in 'Track 7,' a 'national stage' acts as a mechanism to conserve and protect the diversity of regional cultures and participates in shaping and moulding these regional cultures at the same time. Mobile concerts require portable buildings to accommodate residential spaces, and storages for temporary stage structures. In order for this idea to materialize, a type of architecture which responds to change is required.

In his book, House in Motion, Robert Kronenburg defines mobile architecture as "those forms that have a strictly ephemeral nature - that are movable in some form, and are designed specifically for deployment in different situations and/ or locations." 58 In early human's survival over the severe environment, the ability to move from territory to territory was essential. The migration of prey; seasonal patterns of vegetation; and change in climate were major factors which influenced the movement of Nomadic peoples. Those nomadic people had no permanent geographical base; instead, their possessions were carried with them from place to place. Objects for living had to be kept simple and must be small and minimal limited to the carrying ability of humans and animals.

\section{Circus}

More recent precedents of large moving performances carried by train can be referenced back to the circus in the early twentieth century. Structural components of a circus have the ability to be shipped by train from city to city. The framed structure and the tension structure are two basic forms of large circus tent. 59

\footnotetext{
58 Kronenburg, Robert. Houses in Motion (Chichester: Wiley-Academy, 2002), 9.

${ }^{59}$ Ibid., 43.
} 
The framed structure consists of a tent spreading evenly as a weatherproof skin over a structurally independent timber or metal frame. Cirque Palisse adapted this structure. It lasted from 1911 to 1941 . Covered with canvas, Cirque Palisse had a timber frame structure with a 36 meter diameter to accommodate audience of 3,200 people. 60

Tension-structured tents are much lighter than the framed structure ones. Similar to the form of an umbrella, a single central pole erects a conical tent which is held in place with tension cables. The Barnum and Bailey Greatest Show on Earth was one of the largest circuses to use this tension structure. The circus toured Europe several times in the late nineteenth and the early twentieth century. The 1897-1902 circuses used fourteen tents on their sites. The largest tent measured 130 meters by 54 meters to accommodate audiences of 10,000 people. The complex had three rings and two stages. The structural components required seventy wagons to be towed by four trains for transportation from site to site. ${ }^{61}$

\section{Cross-Country Musical Tours}

To survive, the movement of a nomadic people follows the migration of prey and seasonal patterns of vegetation. To perform, the route of a music tour follows populations and concerts are staged for audiences. The music tour is a very conventional means for moving performances from city to city. Most Canadian cities with large populations locate along the border. The route of Canadian music tours usually goes through those cities linearly from the east to the west. (Fig. 7 and Fig. 8) Road trips on buses have been popular for music bands since the passenger services have been dramatically reduced on railroads. Despite all of this, however, several revival cultural activities have been accommodated through the

\footnotetext{
${ }^{60}$ Kronenburg, Robert. Houses in Motion (Chichester: Wiley-Academy, 2002), 43.

61 Ibid.
} 
use of trains. Festival Express and Holiday Train are two major cross-country musical tours within Canada that have been facilitated by transcontinental railroads.

Powered by the Canadian National Railway in the summer of 1970 , the rock festival, Festival Express was staged in three major Canadian cities: Toronto, Winnipeg and Calgary. Rather than flying to each city, traveling by train provided more opportunities for interactions among rock bands such as The Grateful Dead, Janis Joplin, and The Band. Train carriages provided a communal space for jam sessions ${ }^{62}$ and parties when traveling between cities. The communal space provided by train was larger than what a bus could provide. (Fig. 9)

The Canadian Pacific Railway has been hosting an annual musical program, Holiday Train, over the past ten years. During the winter seasons, starting from mid November to mid December, entertainers and musicians board a designated train decorated with Christmas lights (Fig. 11). The train then travels from the east coast to the west coast through Canadian and American cities. Along with the performances, the program raises awareness for local food banks by collecting food and money donations. Holiday Train reaches over a hundred communities in both Canadian provinces and American states (Fig. 10). During the 2008 season, performers included "Canadian Country Music Hall of Fame member, Tracey Brown, CCMA winner Johnny Reid, Shaun Verreault, Singer/ Guitarist/ Song-writer for blues-rockers and Canadian live favourites Wide Mouth Mason and Juno award-winning singer and songwriter Melanie Doane." ${ }^{63}$ While Holiday Train stops at small towns, one of the train cars opens up and becomes a stage on tracks. Surrounded by standing audiences,

\footnotetext{
62 Musicians play together without preparation.

${ }^{63}$ Canadian Pacific. Holiday Train. 2009.

http://www8.cpr.ca/English/General+Public/Holiday+Train/default.htm (accessed 2009).
} 
outdoor concerts were staged at small town stations. In this way, instead of piling in for concerts in big cities, bands are now coming to small towns.

Both Festival Express and Holiday Train music tours have been accommodated by conventional passenger train carriages; the size of the music tours were limited by the spaces of those train carriages. Festival Express required temporary stages to be constructed separately from the train cars. While Holiday Train modifies a box car into a small concert stage by installing fold-out doors, the size of the stage in this instance is limited by the space of the modified box car. (Fig. 12) In comparison to Festival Express, Holiday Train has better flexibility in reaching out to small towns, but it accommodates a relatively smaller audience. 


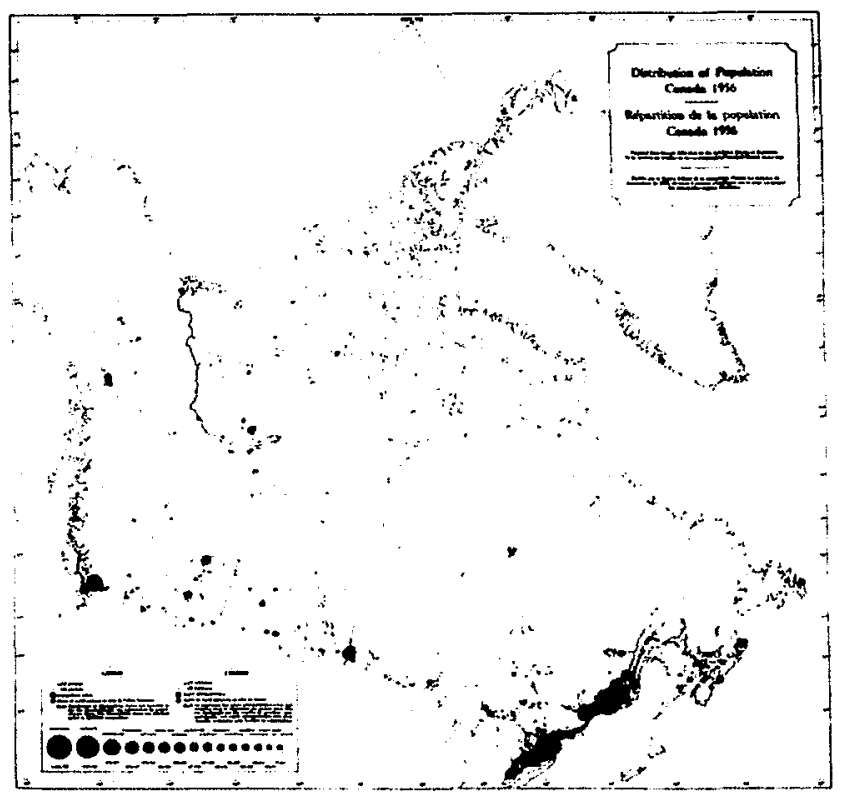

Fig. 7 Distribution of Population in Canada, 1956

http://www65.statcan.ca/acyb04/1957/acyb04_19571360-eng.htm

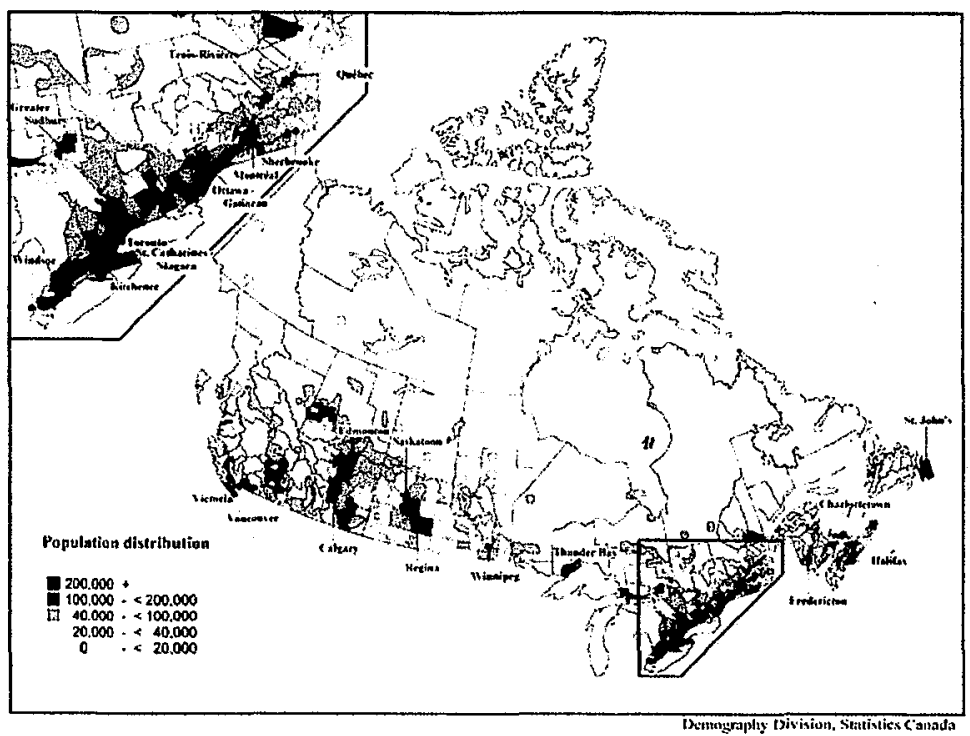

Fig. 8 Population Distribution as of July 1, 2007: by Census Division (CD), Canada http://www.statcan.gc.ca/pub/91-214-x/2007000/4121648-eng.htm 

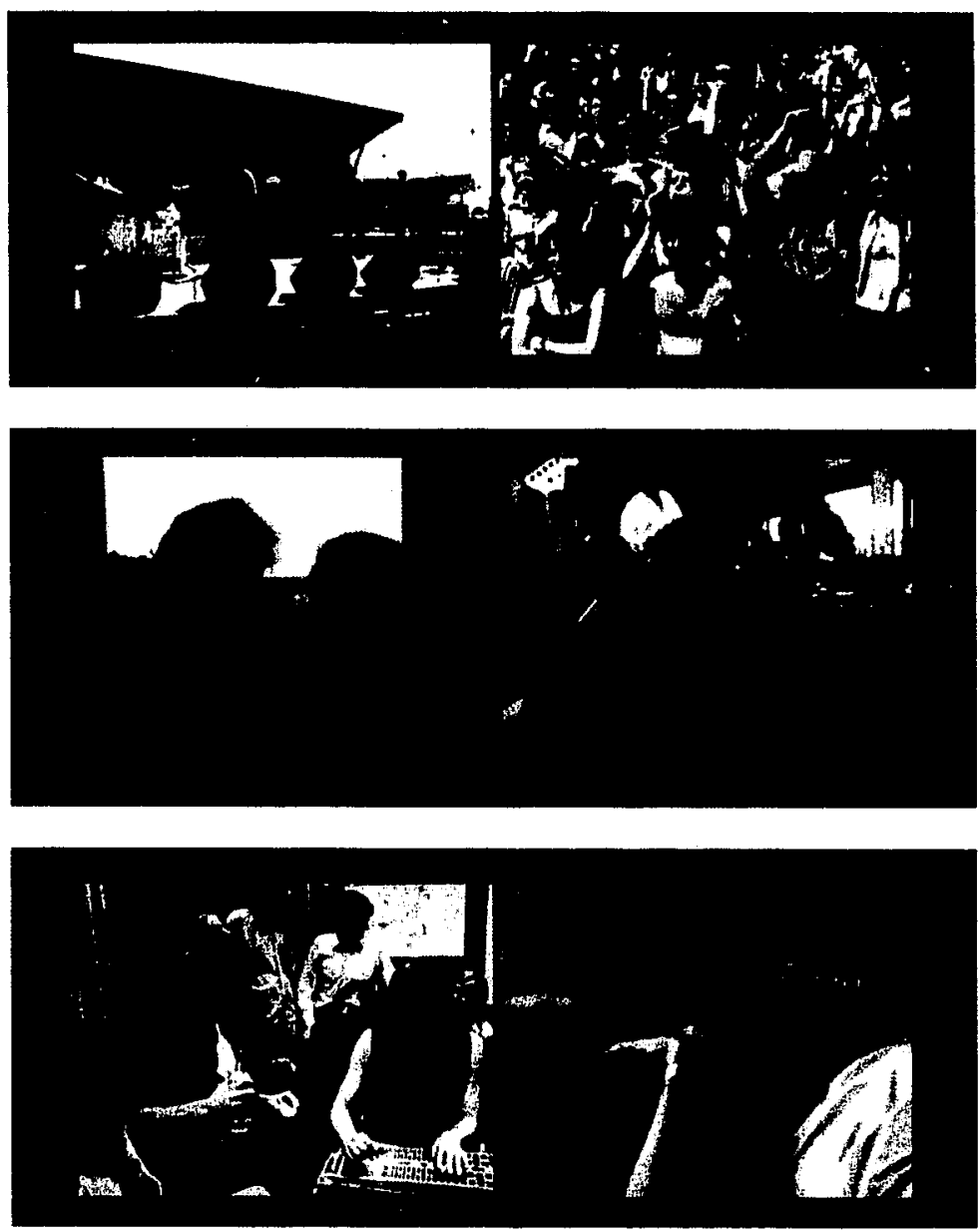

Fig. 9 Festival Express: Screenshots from Festival Express Documentary DVD 


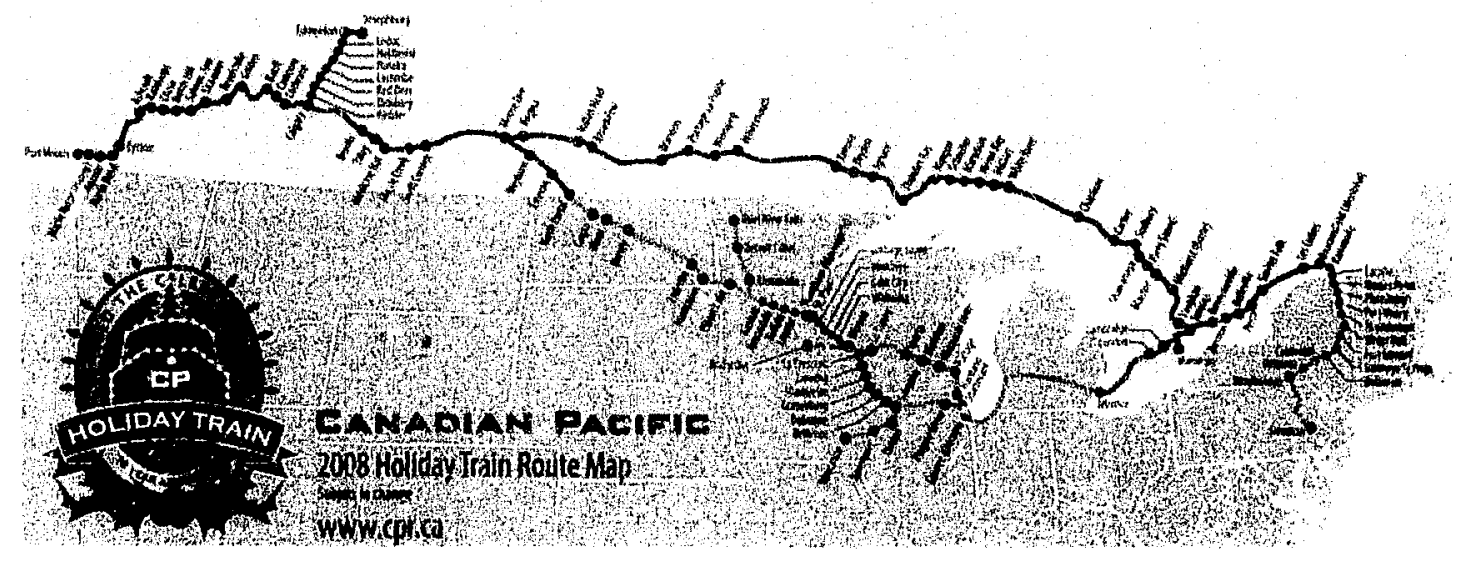

Fig. 102008 Holiday Train Route Map

http://www8.cpr.ca/cms/English/General+Public/Holiday+Trai!t/ i . dult.htm 


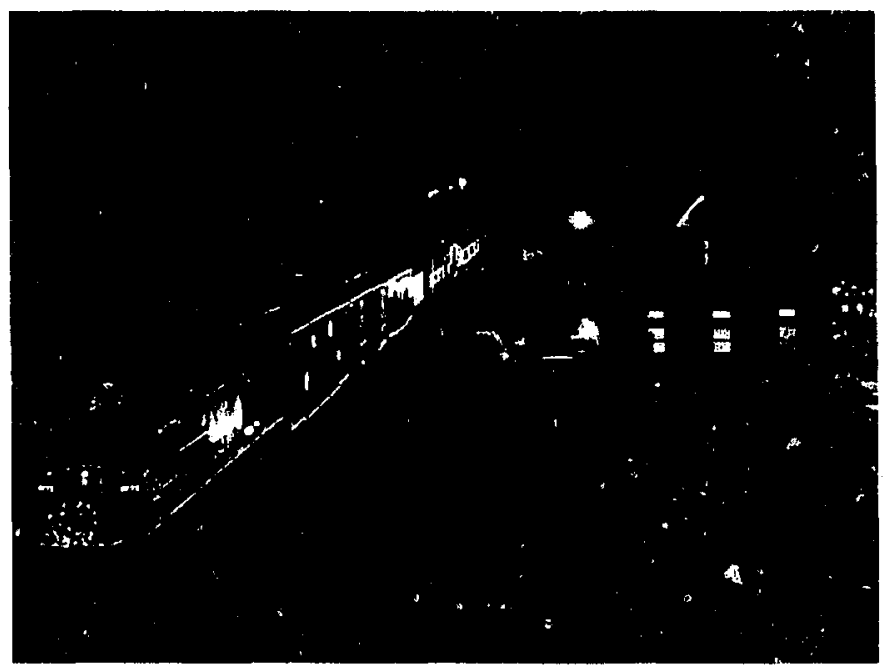

Fig. 11 Holiday Train: Concert at La Crosse

http://www8.cpr.ca/c.. s/English/General+Public/Holiday+Train/Photo+gallery/ defaulthtm?Show=La\%20Crosse

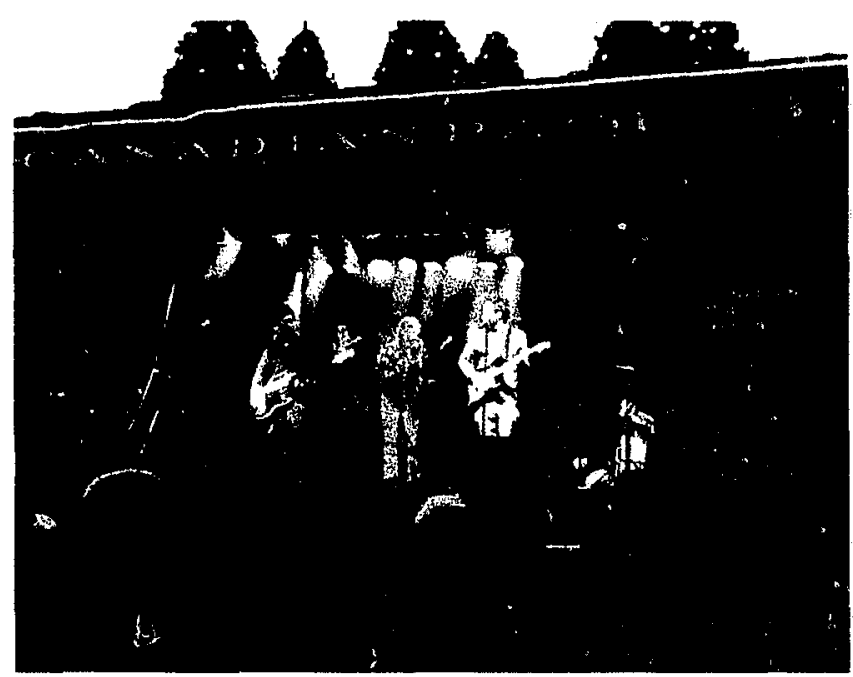

Fig. 12 Holiday Train: Strge Converted from a Box Car.

http://www8.cpr.ca/cms/English/General+Public/Holiday+Train/Photo+gallery/ default.htm?Show=Entertainers 


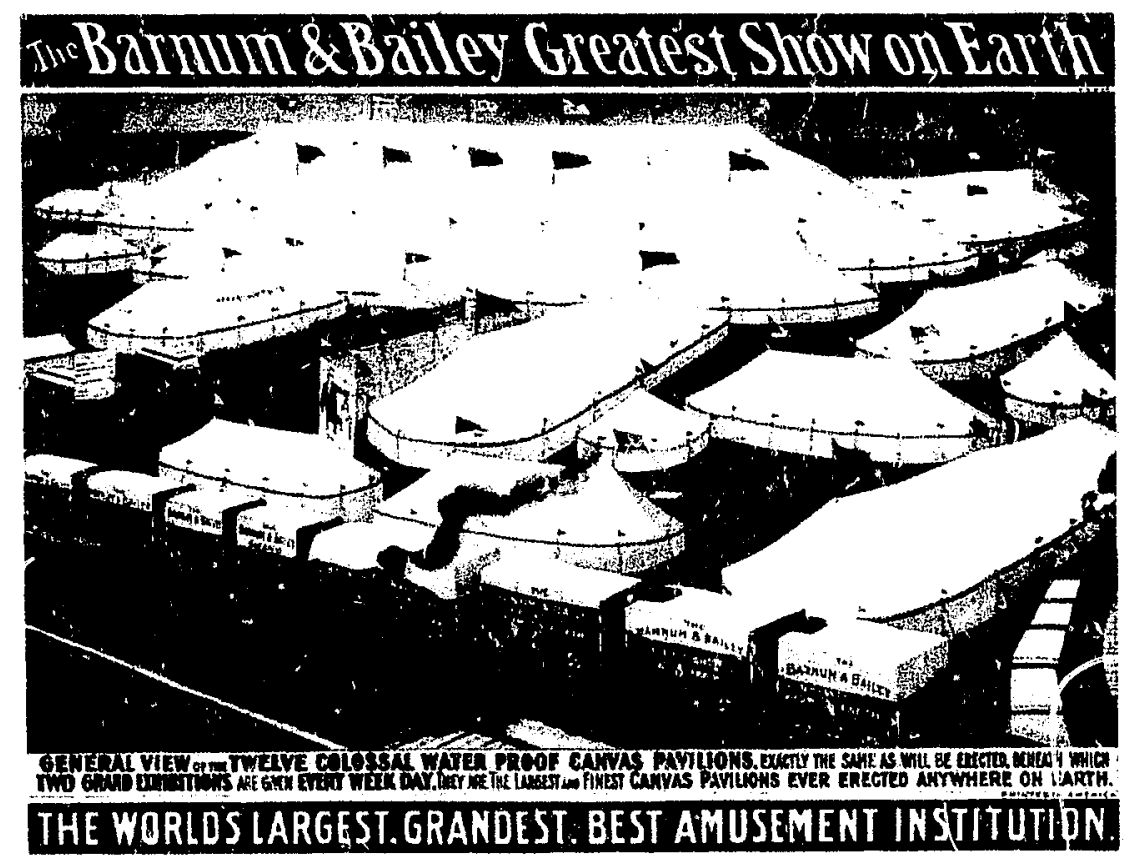

Fig. 13 Barnum \& Bailey greatest show on Earth Poster

http://en.wikipedia.org/wiki/File:Barnum_\%26_Bailey_greatest_sho'N_on_Earth_poster.jpg 


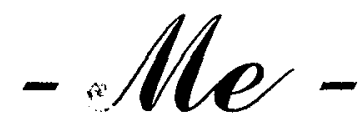

\section{Track 9: A Proposal for the Future}

Based on the above arguments, this thesis proposes to establish an annual music festival, which will be facilitated by the existing railway network, to maintain the diversity of Canadian society. By recognizing, sharing, and understanding the music from diverse communities, Canadians are provided opportunities to also understand the diversity of regional cultures and discover their common grounds to form mutual support. The circulation of art expression and creativity through the railroads, participates in the shaping of the Canadian music scene.

The argument of this thesis is that - based on Wyman's ideology for Canadian society - even today, pop music facilitated by the existing Canadian railway system could help us to understand diverse cultures in different regions of Canada. The railroad could function like a blood vessel system which carries fresh ideas to various parts of Canada and in so doing stimulates the creation of art. Pumped with heartbeats, the circulation of art expression and creativity enhances the cultural integrity of a nation, but still maintains its regional cultural diversity. The design portion of this thesis proposes an annual cross-country music festival, named 'Music Tracks.' Music concerts will be staged on two train yards in both Ottawa and Vancouver. Riding on trains, small town bands will travel from their hometowns in different regions of Canada to the festival sites. 


\section{The Program}

Once registered with 'Music Tracks,' those bands which are performing in local bars, pubs, or even their own garages will be provided with a 'national stage' in the annual festival. An audition jury will select twenty bands annually from the registration list. In every summer, carried by specially-designed carriages, twenty selected bands from different regions of Canada will travel separately from their own towns to the Ottawa festival site along railroads. They will make stops and perform in small towns along railroads. While traveling by train, a railcar is used as a communal space where individuals can meet and stay connected. Just as conversations arise on passenger trains, ideas will be exchanged and values will be shared in the communal space. This communal space is provided beyond the limits of city boundaries; similar to music which connects mankind beyond spaces itself. After the bands arrive in Ottawa, their carriages will be transformed into temporary communal residences and concert stages. After a series of concerts in Ottawa, the bands will travel all together to Vancouver's festival site where their colony of railcars will be setup once again (Fig. 14).

\section{Festival Sites}

The previous downtown Ottawa train station was converted into a conference hall. "In the 1960 s, plans to beautify Ottawa called for the removal of all downtown railway tracks. A new station opened farther out, and the historic Union Station was threatened with removal. Ottawa however has long prided itself on its heritage and the station was preserved as a conference hall. The new station, Union Station was designed by architect, John C. Parkin, 
and constructed from 1965 to $1966 .{ }^{64}$ Railway tracks branch off into twelve tracks at the station. Six tracks have been abandoned and continue to remain inactive. The land occupied by the six tracks was sold for office tower development ${ }^{65}$. The design portion of this thesis proposes to reuse these abandoned tracks to facilitate mobile architecture as a music festival site (Fig. 15).

The Burlington Northern Santa $\mathrm{Fe}^{66}$ rail yard is proposed to be 'Music Tracks' festival site in Vancouver. The site is about 800 meters from Pacific Central -Vancouver union train station. It is on the north side of the Great Northern Way Campus (Fig. 16). The empty field on the east is used for potential parking spaces.

\section{Mobile Architecture in Practice}

The materialization of 'Music Tracks' must rely on portable buildings and relocatable concert stages (according to Kronenburg's definition of mobile architecture). ${ }^{67}$ The design of mobile architecture for traveling musicians is facilitated by existing Canadian railway infrastructure. When a 'musician colony' is established at either the eastern or western festival sites, it consists of four sectors: Residence, Reception, Audience, and Concert Stage (Fig. 17, Fig. 18, and Fig. 19).

\footnotetext{
${ }^{64}$ Heritage Research Associates Inc. Union/VlA Rail Station, Ottawa, Ontario. Railway Station Report, Historic Sites and Mounments Board of Canada, 39

65 Ottawa Train Yards - Ottawa's Premier Shopping District. Future Growth. 2009. http://www.ottawatrainyards.com/future.html (accessed 2009).

66 Prosperity of Burlington Northern and Santa Fe Railway. BNSF Railway. http://www.bnsf.com/ (accessed 03 2009).

67 Kronenburg, Robert. Houses in Motion (Chichester: Wiley-Academy, 2002), 9.
} 
The 'Residence Sector,' the residences of band members, is an assembly of twenty railcars (Fig. 20 and Fig. 24). Those railcars are designed to accommodate music bands during their travel from city to city and from town to town along the railway. Each band will be given two railcars: the 'Sleeper Car' and the 'Canvas Car' (Fig. 31 and Fig. 32). When a band travels, both the 'Sleeper Car' and the 'Canvas Car' will be attached to a conventional passenger train towed by a diesel-electric locomotive. In order to comply with the widelyused Loading Gauge ${ }^{68}$ in North America, twenty 'Sleeper Cars' and twenty 'Canvas Cars' with dimensions of 1.5 meters in length, 3.2 meters in width and 2.7 meters in height, will be prefabricated and mounted on forty re-used CPR 521300 Series flat cars which have a height of 1.3 meters (from the top of the rail to the top of the flat car) ${ }^{69}$.

The 'Sleeper Cars' are designed for three modes: first, rolling on tracks (Fig. 33 and Fig. 34); second, performing in small towns (Fig. 35); third, being assembled with other 'Sleeper Cars' at the music festival sites (Fig. 36). A kitchen, two lavatories and one shower are the standardized utilities of a 'Sleeper Car'. A HVAC system is integrated and concealed in the roof.

In order to be flexible in motion, furniture in the 'Sleeper Car' has to remain compact and small. Similar to Alan Wexler's Crate House ${ }^{70}$ and Andrea Zittel's Living Unit 71 , a crate is specially designed to contain objects which are required for daily living in a regular house.

\footnotetext{
68 The envelope or contoured shape that all railroad cars must fit within in order to pass through tunnels. Loading Gauge. http://www.bookrags.com/wiki/Loading_gauge (accessed 02 2009).

69 Forty-one Canadian Pacific Railway flat cars, Series 521300-521340, were built for freight transportations and were in service from 1976 to 1997. Canadian Pacific Railway Series 400000-999999. http://www.nakina.net/cp/cp4.html (accessed 02 2009).

${ }^{70}$ Kronenburg, Robert. Flexible: Architecture that Responds to Change (London: Laurence King Publishing Ltd, $2007)$.

71 Portable Architecture - and upredictable Surroundings -. Arian Mostaedi, 2006.
} 
Two folding beds, one desk, and one bench are stored in a crate within the 'Sleeper Car'. Built-in lockers, shelves, and drawers are also integrated into the crate (Fig. 44, Fig. 45, and Fig. 46). The 'Sleeper Car' has the maximum capacity to accommodate six band members with all three crates fully equipped on board.

The communal space is arranged in the center of a 'Sleeper Car.' During the jam sessions, when the train is rolling, crates mounted on wheels are piled up at one end of the 'Sleeper Car.' (Fig. 33) For sleeping purposes; however, the crates are pulled out and beds are unfolded (Fig. 34). Depending on the size of the band, a second 'Sleeper Car' may be added. Large musical instruments such as pianos, cellos and drums can also be carried in a second 'Sleeper Car.' When a band stops to perform in a small town, their 'Sleeper Car' will be deployed into a small stage (Fig. 35). When the twenty bands gather together at the festival sites, their 'Sleeper Cars' are connected. Crates will be pulled in the connected communal spaces (Fig. 36). Benches and tables will unfold from those crates to provide seating for different bands to meet and play music together.

The 'Canvas Car' is so named after its appearance. The 'Canvas Car' exists primarily to carry sound equipment and temporary structural components for the music festival concert stage. The canvas car is similar to a container which has a clean surface with corrugated metal cladding. Both sides of the 'Canvas Car' provide a perfect opportunity for graffiti. Graffiti artists from the same hometowns as the music bands will be commissioned to create promotional art on the sides of the 'Canvas Cars' for the bands. As a moving canvas, the graffiti art will be shown to the public when the band's carriages are towed by train across the Canadian landscape. When bands arrive at the festival sites, the 'Canvas Cars' deploy into platforms where the audience will stand above the rail tracks (Fig. 38). In addition, 
benches are installed along the edges of the platform to provide alternative seating. Each band's 'Sleeper Car' tows a 'Canvas Car' behind. Twenty bands bring twenty 'Sleeper Cars' and twenty 'Canvas Cars' to the festival sites.

Three of the twenty 'Canvas Cars' will deploy into the base of the main concert stage (Fig. 39). Stage lights, speakers, projectors, and backdrops, will be supported by temporary structures erected on the platforms in the 'Concert Stage Sector' (Fig. 22, Fig. 23, Fig. 29, and Fig. 30). In the 'Reception Sector,' another two of the twenty 'Canvas Cars' will be converted into a bar and a gift shop (Fig. 40 and Fig. 41). In the 'Audience Sector,' the remaining fifteen 'Canvas Cars' will be deployed and become platforms to accommodate the standing space and alternative seating for 1,170 audience members (Fig. 26 and Fig. 21). 


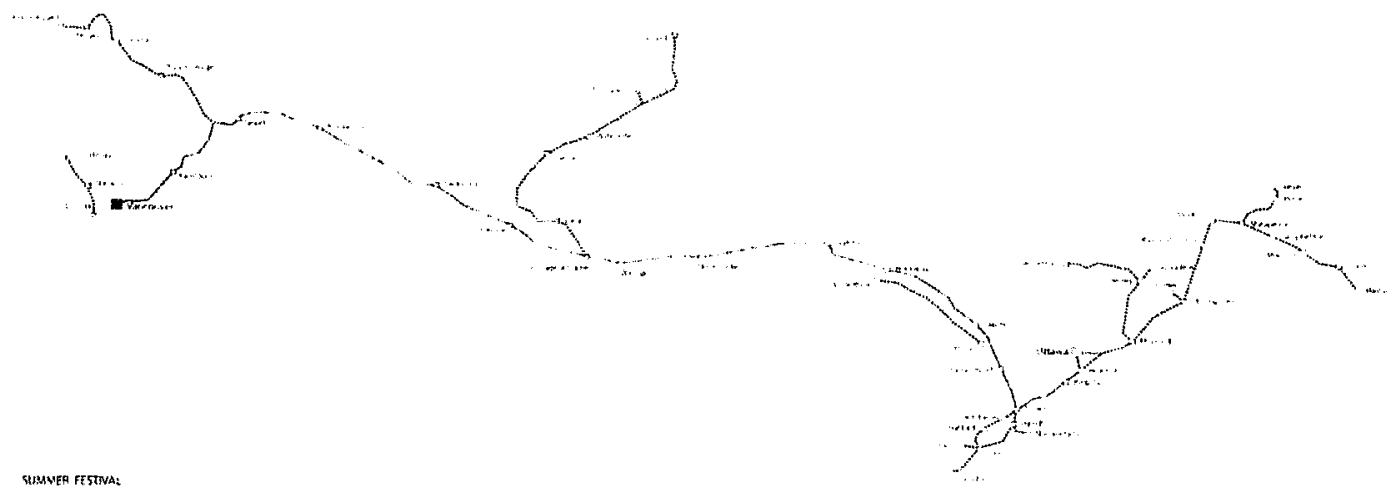

VIHTER CLSTWAL

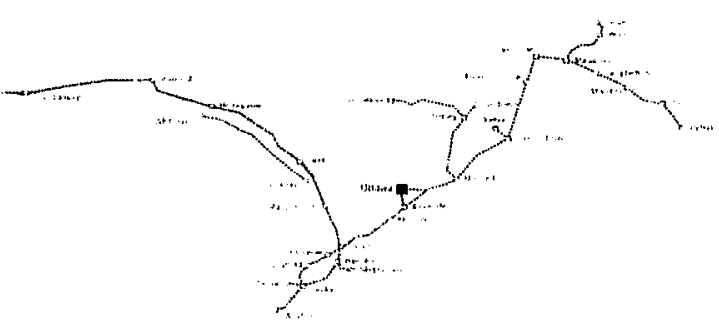

Fig. 14 Proposed Festival Route for 'Music Tracks' 


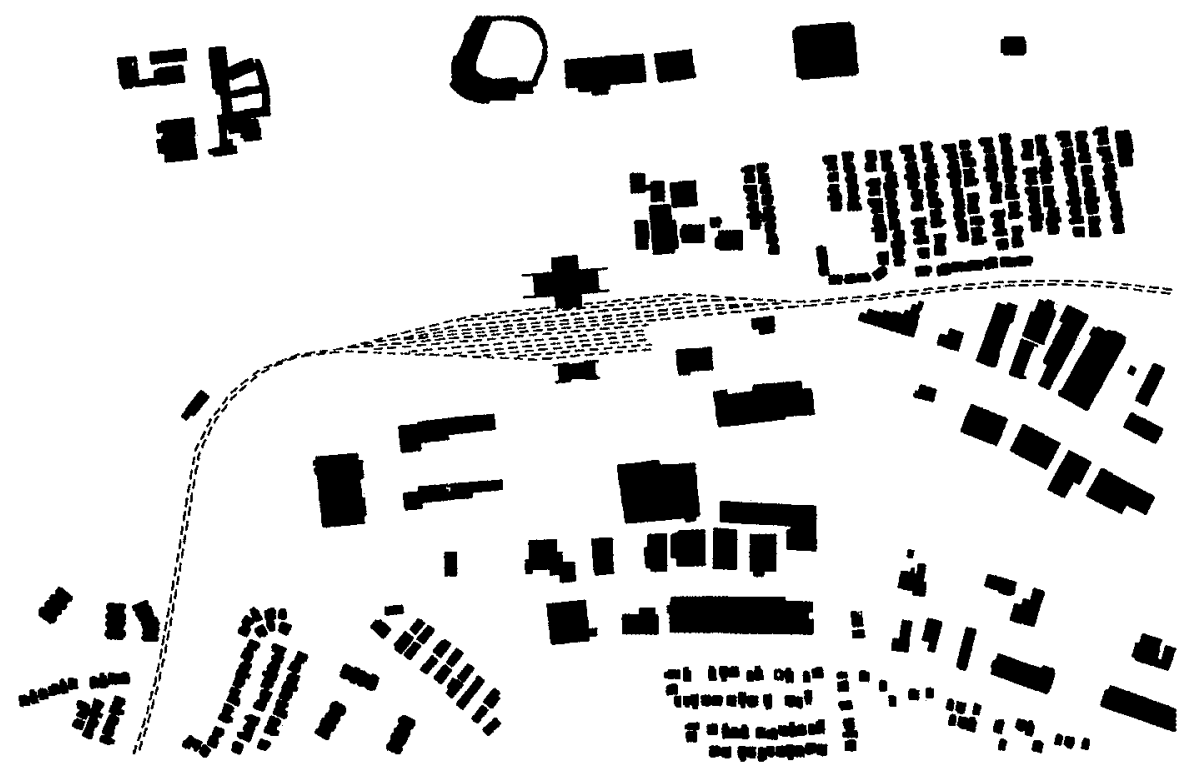

Fig. 15 Festival Site Plan: Ottawa

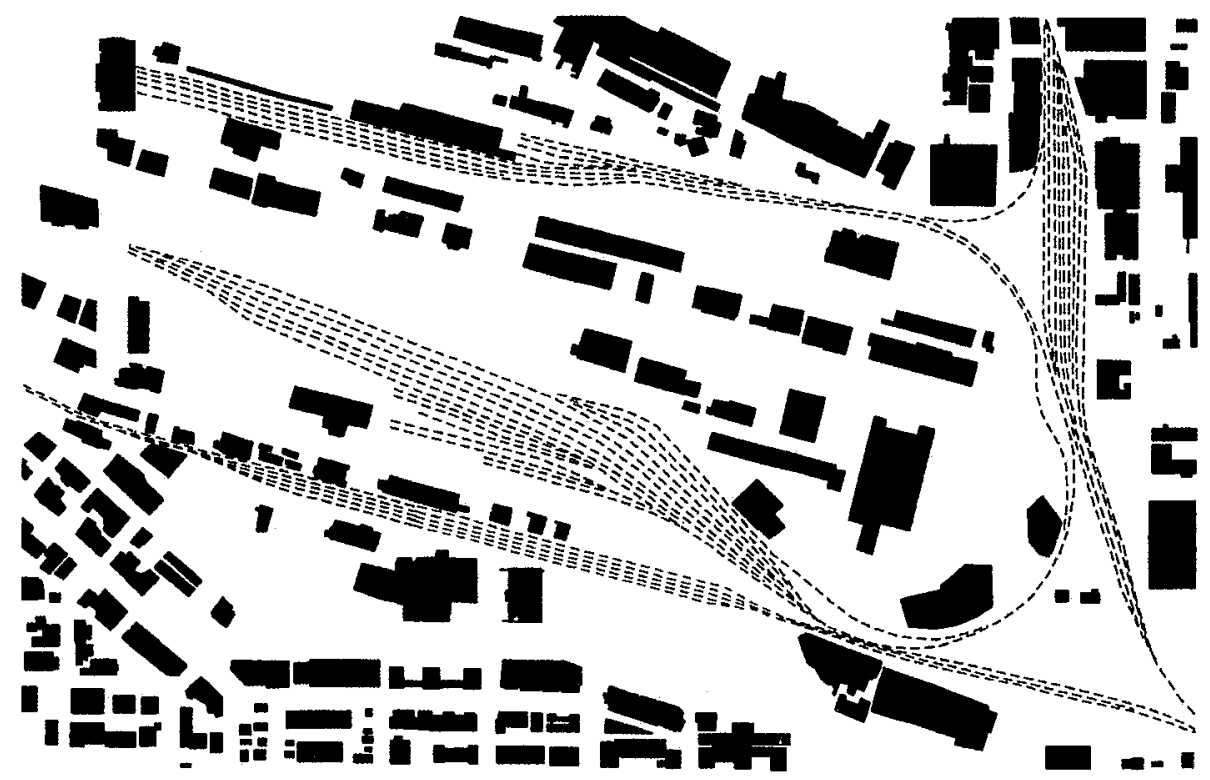

Fig. 16 Festival Site Plan: Vancouver 


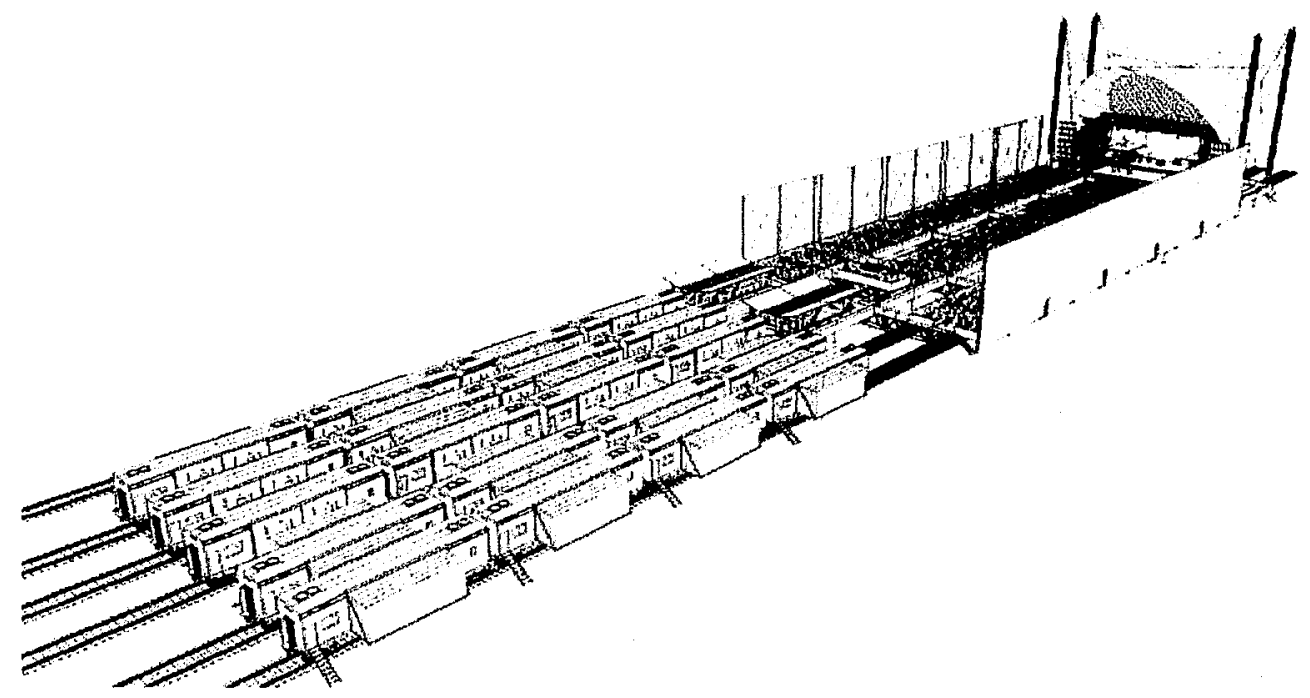

Fig. 17 Perspective View of 'Music Tracks'

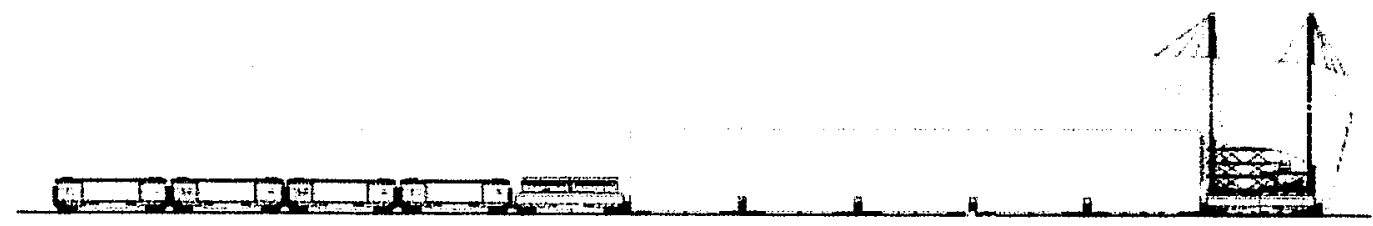

Fig. 18 Elevation of 'Music Tracks' 


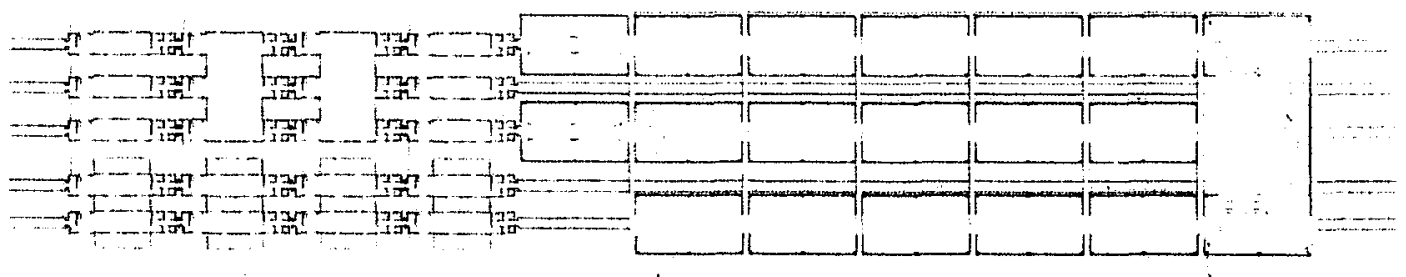

Fig. 19 Plan of 'Music Tracks'

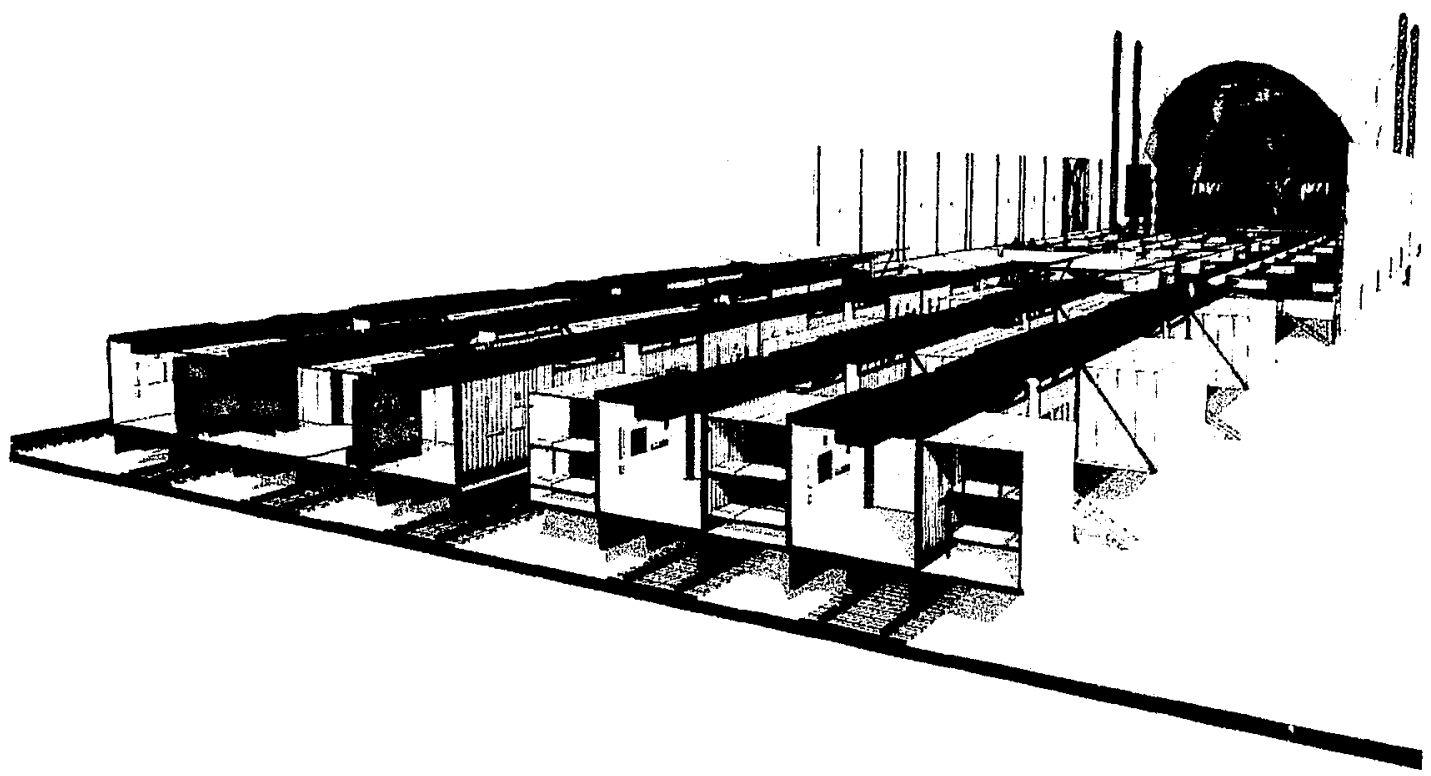

Fig. 20 Section through the Residence 


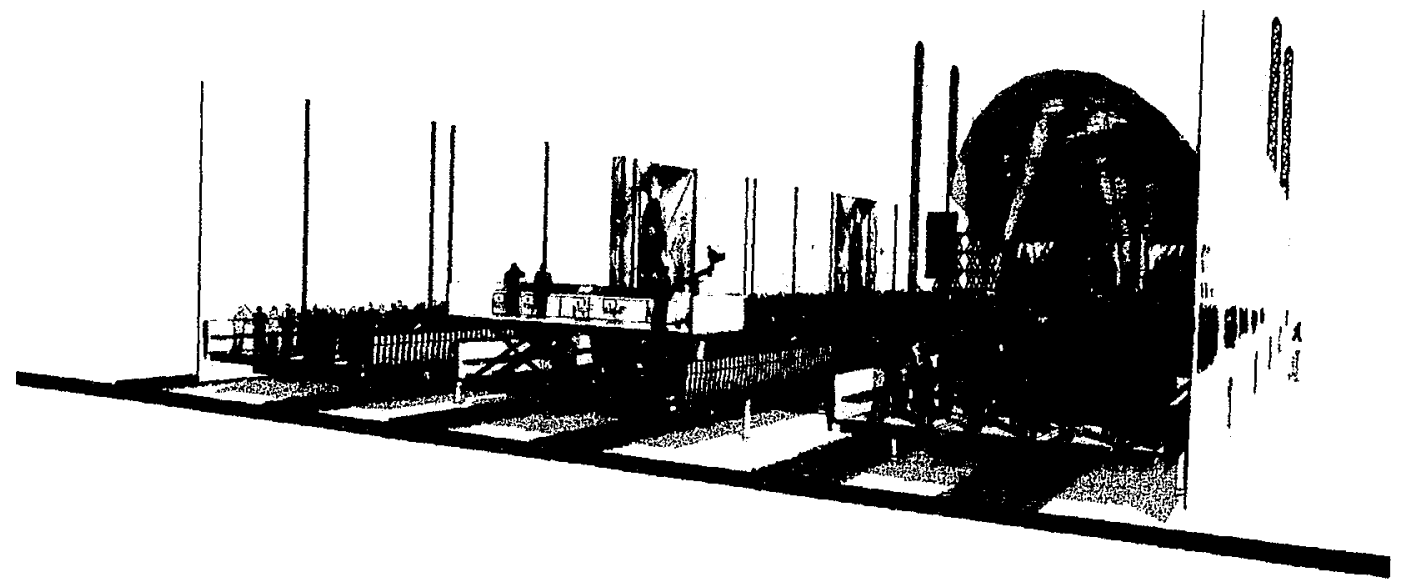

Fig. 21 Section through the Audience Platforms

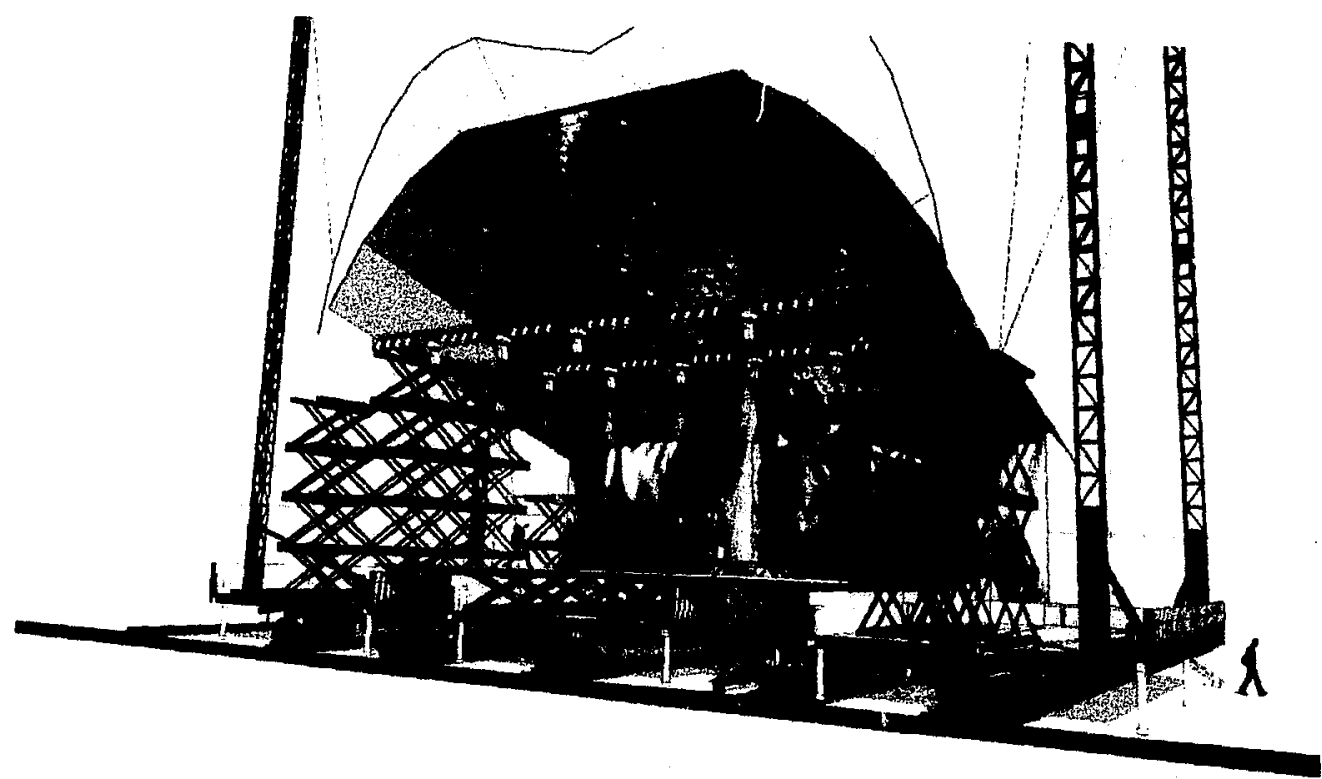

Fig. 22 Section through the Concert Stage 


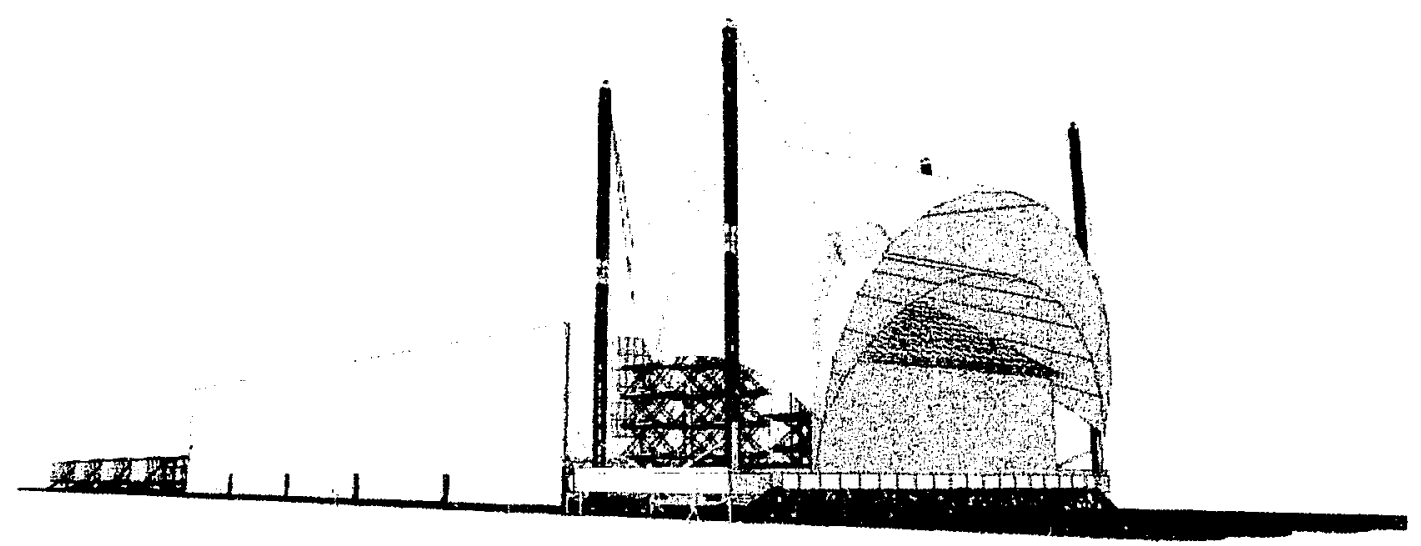

Fig. 23 Perspective View of the Concert Stage

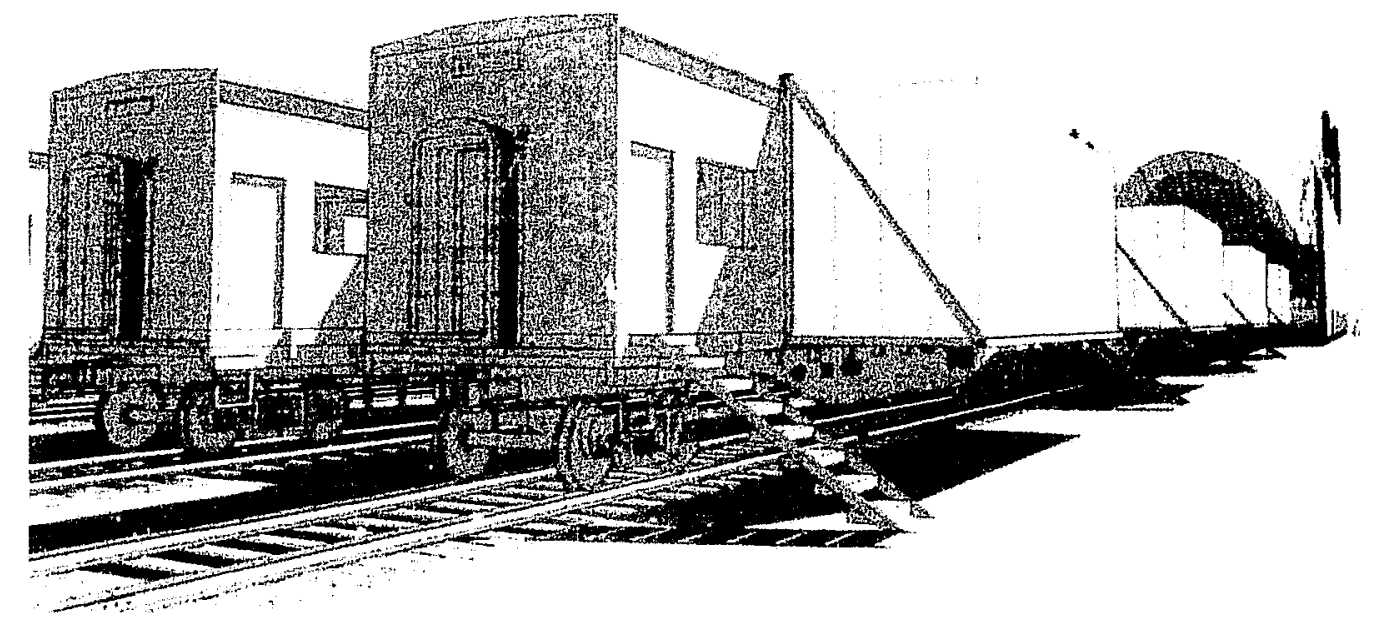

Fig. 24 Perspective View of the Residences 


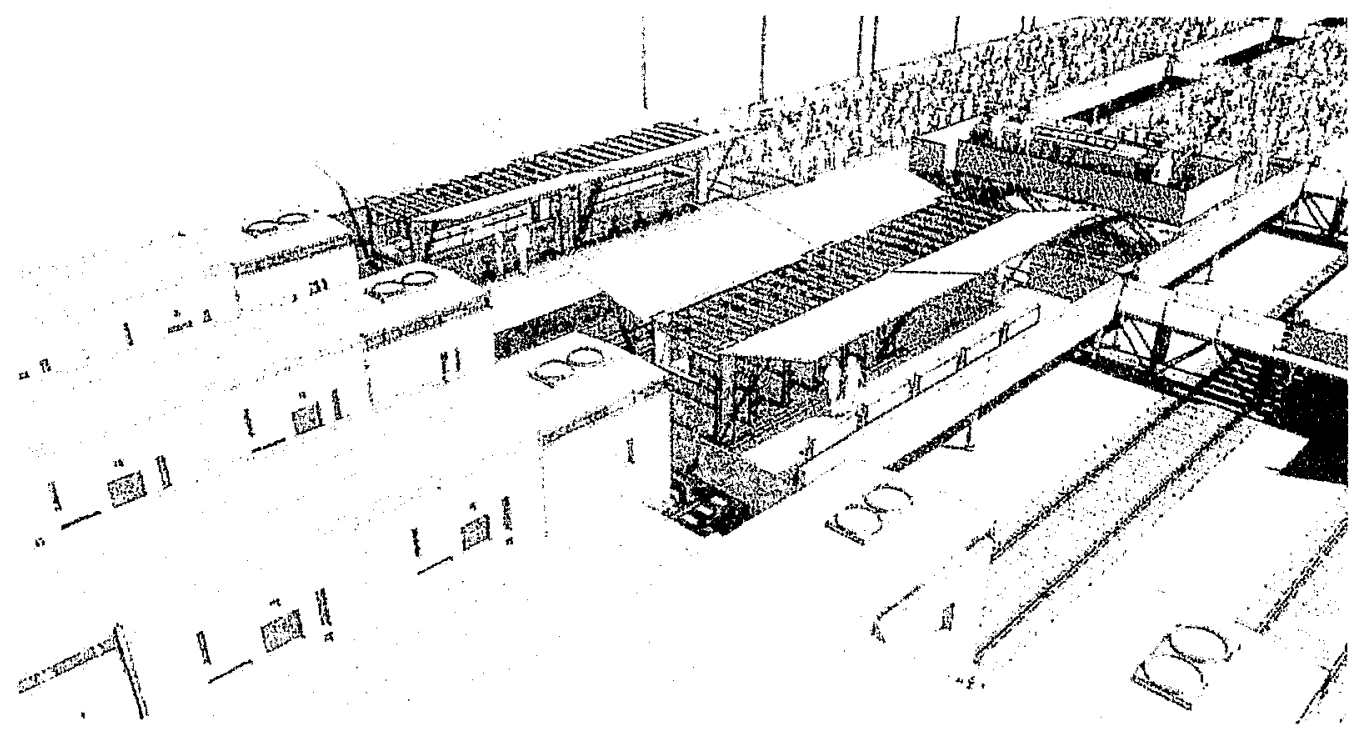

Fig. 25 Perspective View of Bar and Gift Shop

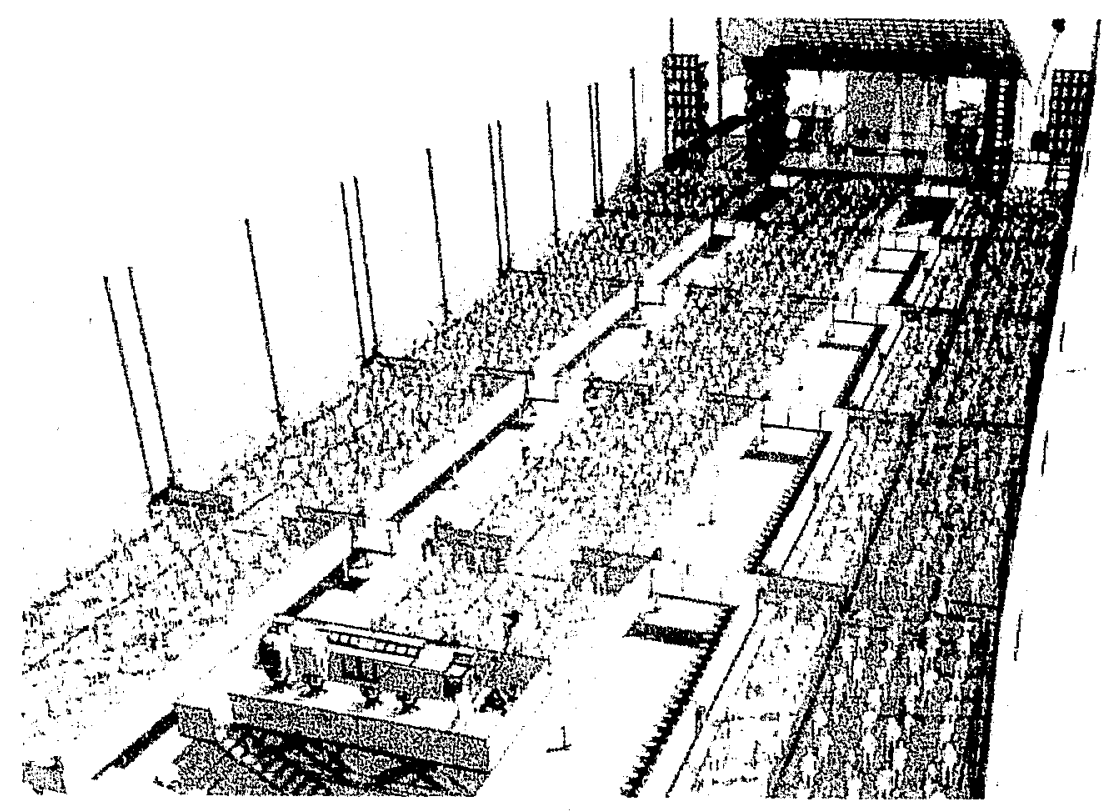

Fig. 26 Perspective View of a Concert 


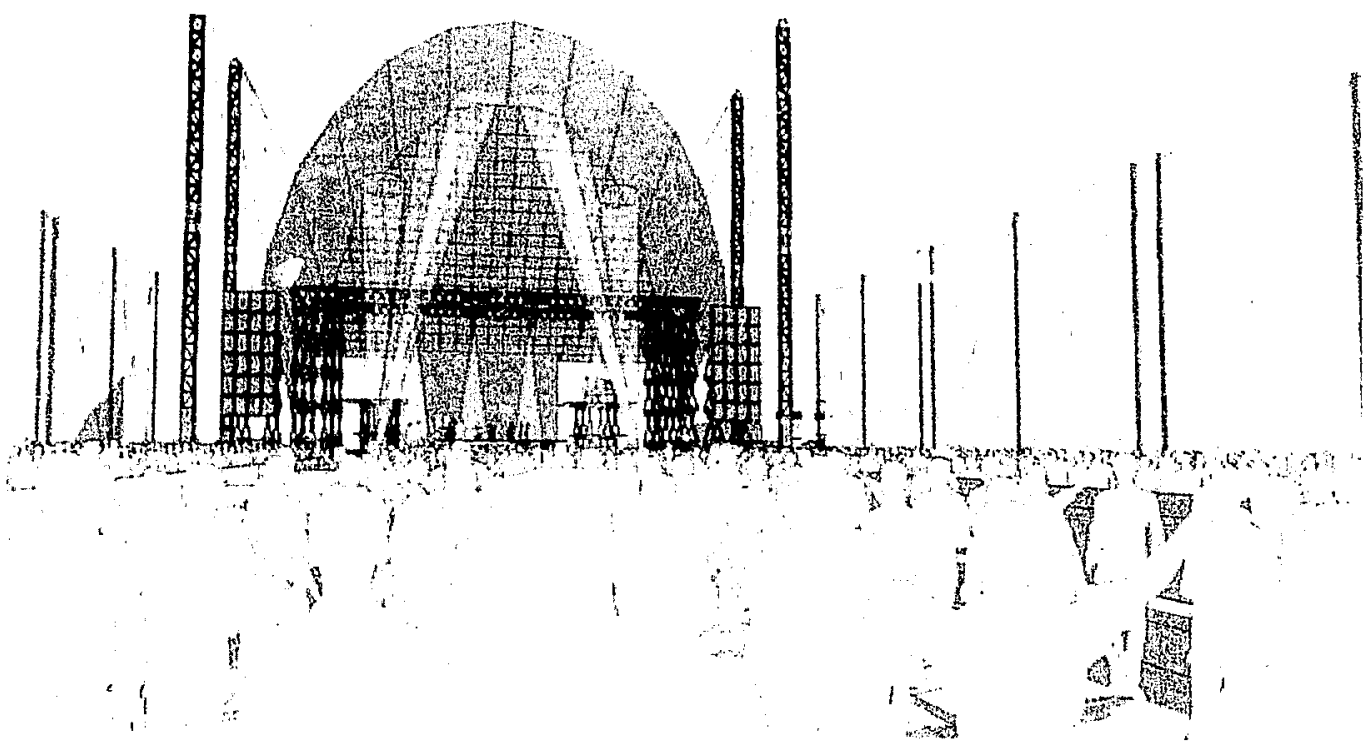

Fig. 27 Perspective View from Audience Pla'form in a Concert

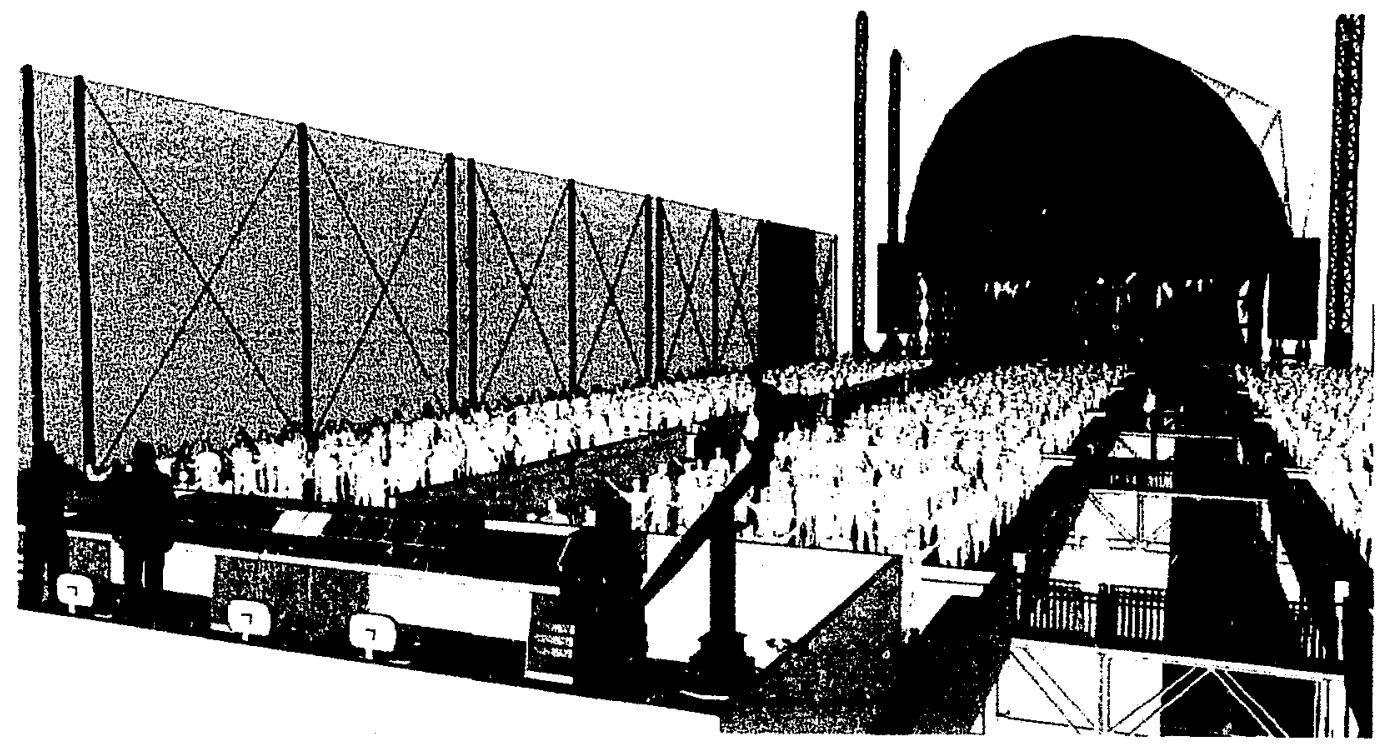

Fig. 28 Perspective View above Sound Control Booth in a Ccrcert 


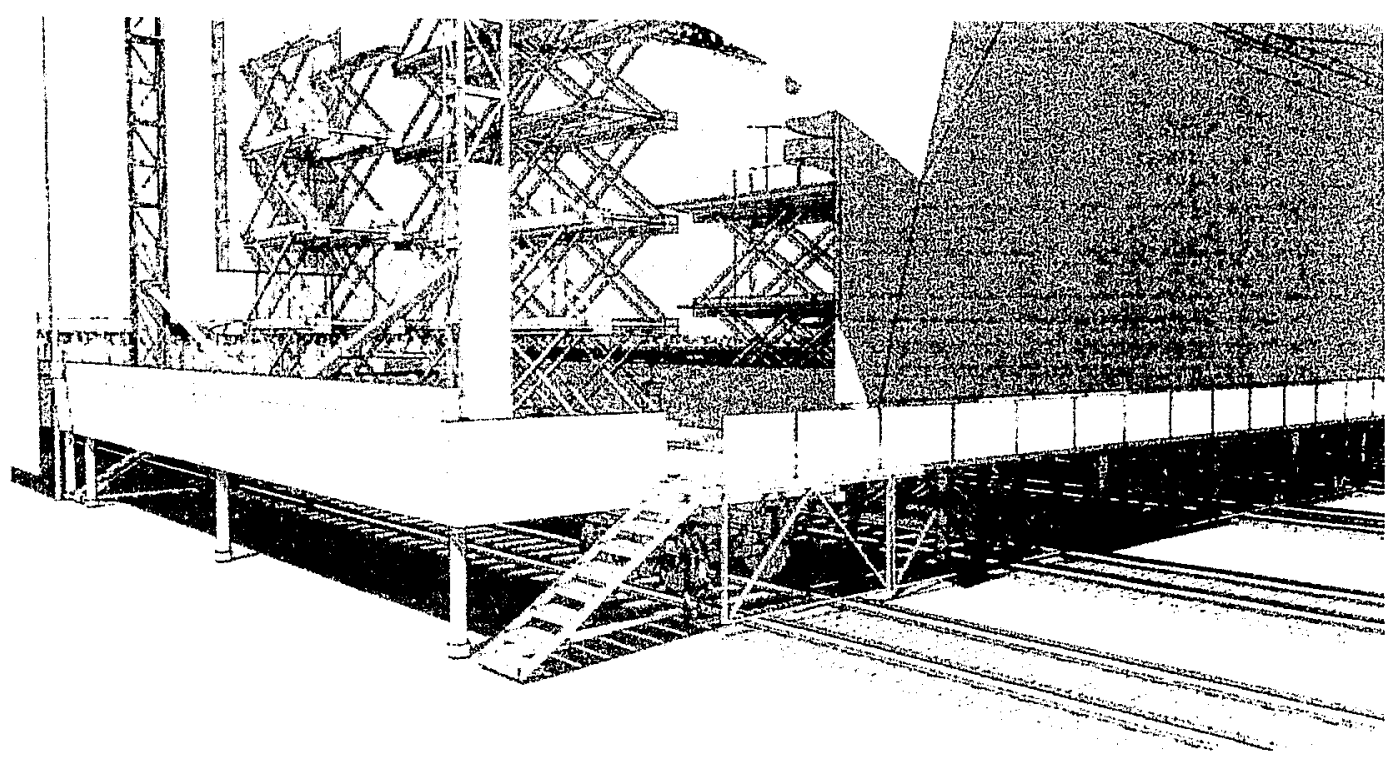

Fig. 29 Concert Stage: Structural details

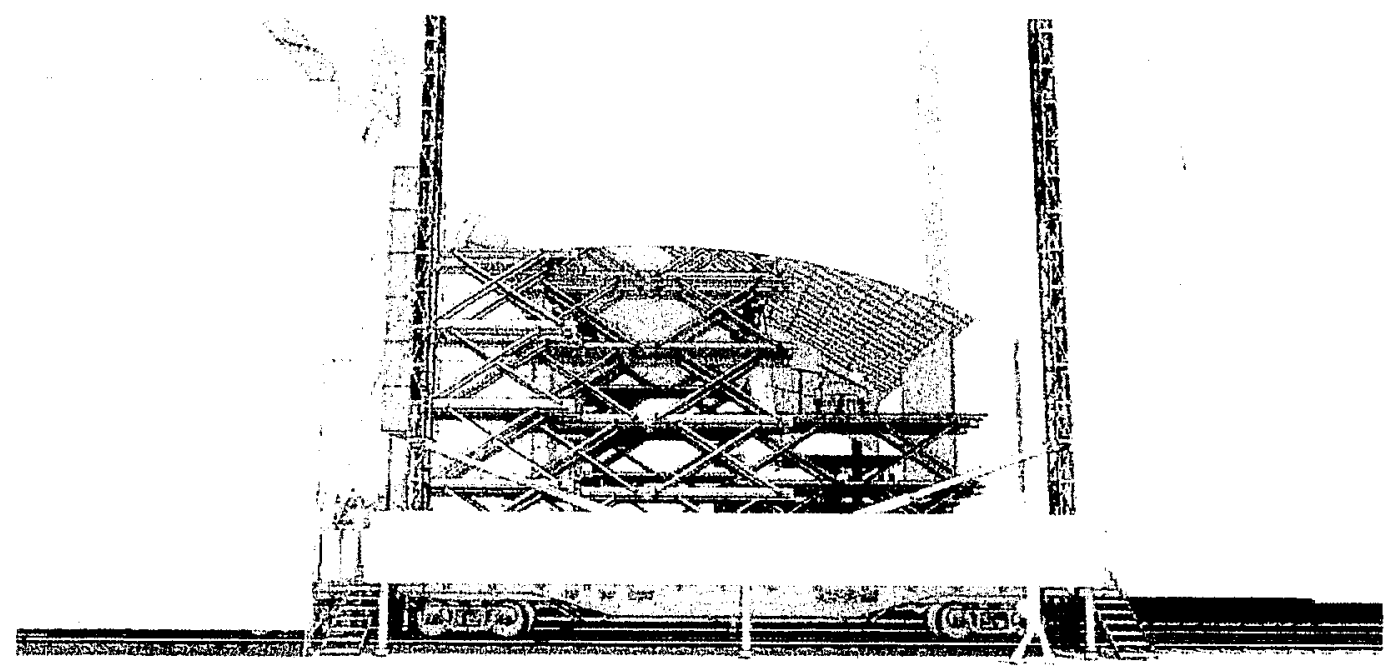

Fig. 30 Concert Stage: Structural details from a side view 


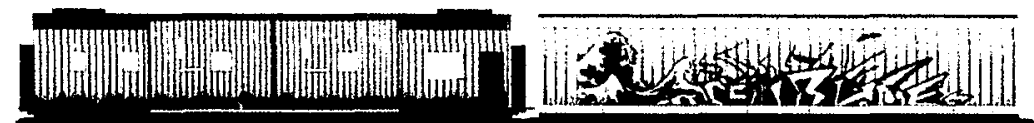

Fig. 31 Elevation of a Sleeper Car and a Canvas Car

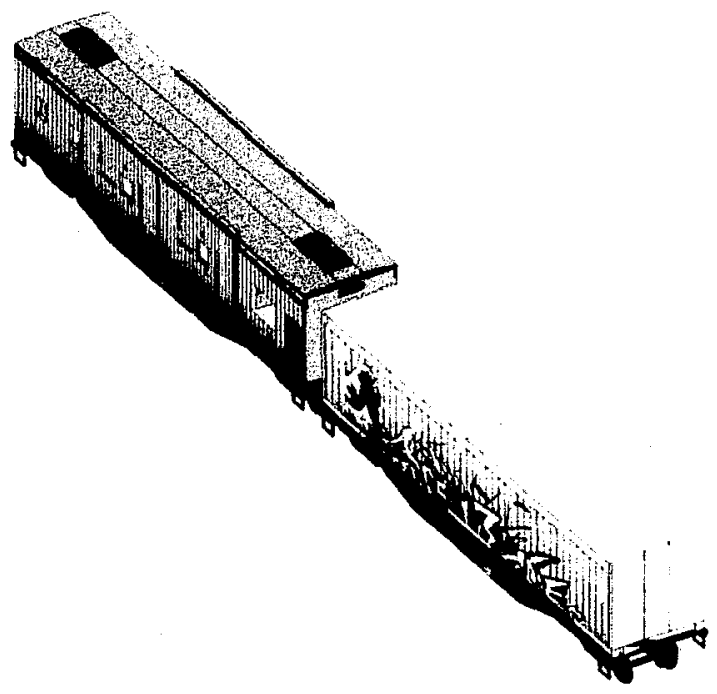

Fig. 32 Isometric of a Sleeper Car and a Canvas Car 


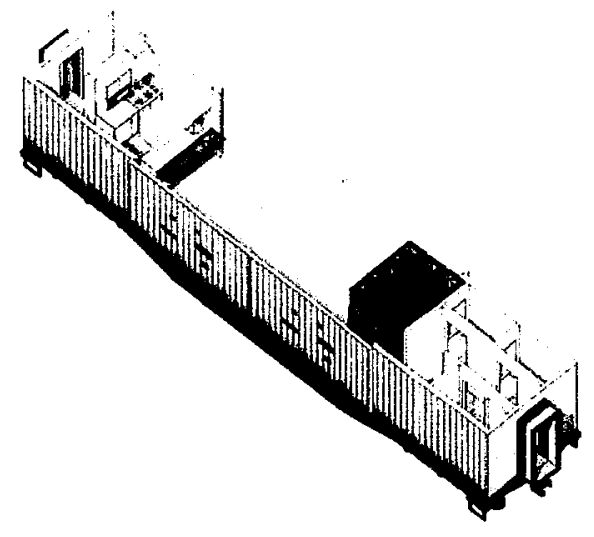

Fig. 33 Sleeper Car in Motion: Communal Space for Jam Sessions

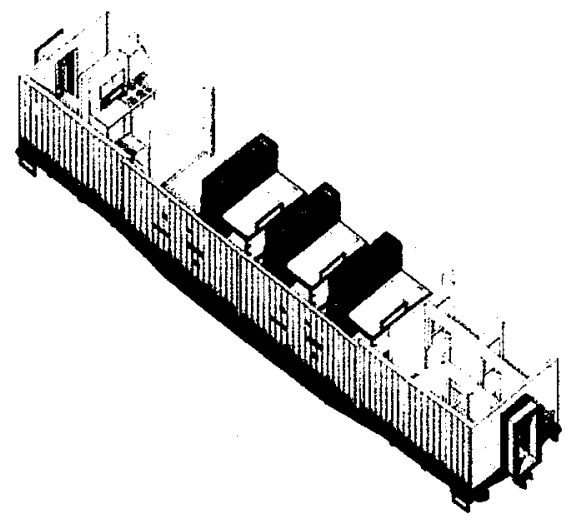

Fig. 34 Sleeper Car in Motion: Beds Unfolded for Sleeping 


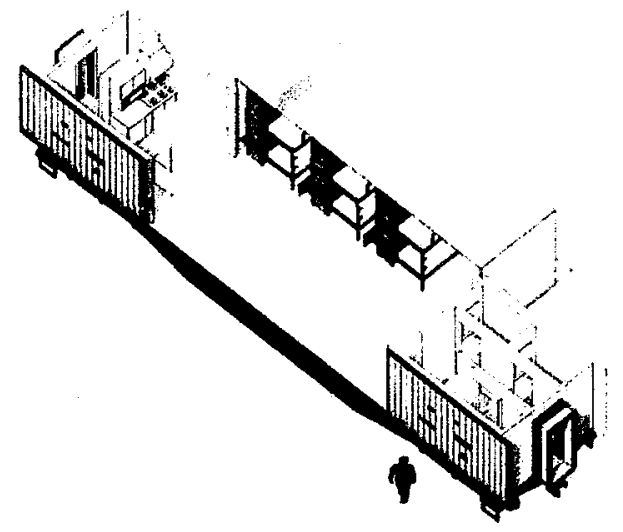

Fig. 35 Sleeper Car Stopping in a Small Town: Converted into Small Concert Stage

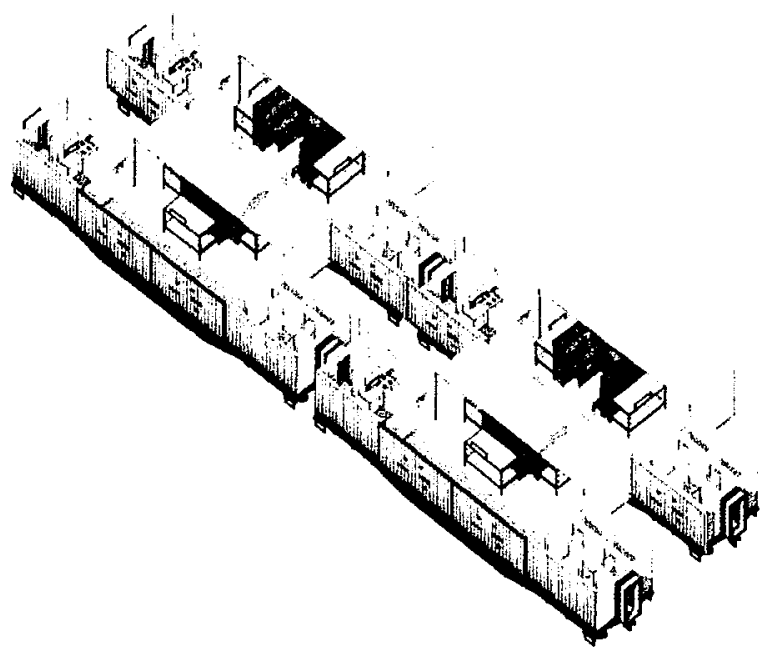

Fig. 36 Sleeper Car Stopping at the Festival Sites: Assembled as a Communal Residence 

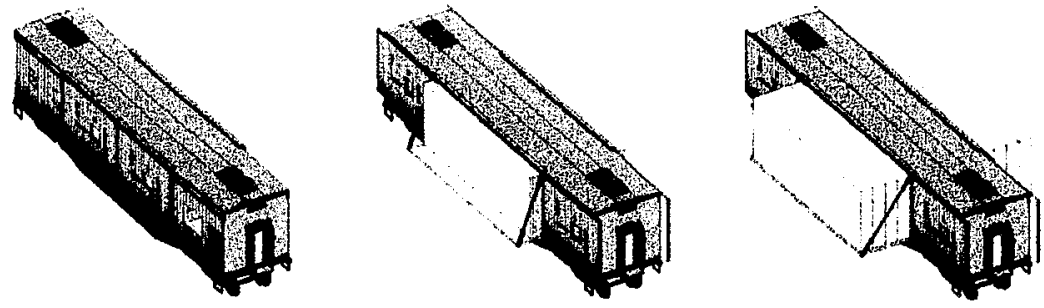

Fig. 37 Sleeper Car: Deployment into a Temporary Residence 

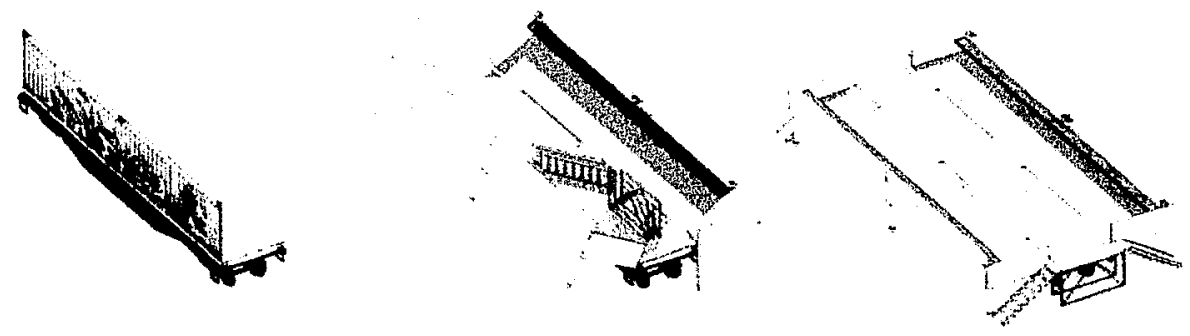

Fig. 38 Canvas Car: Deployment into a platform
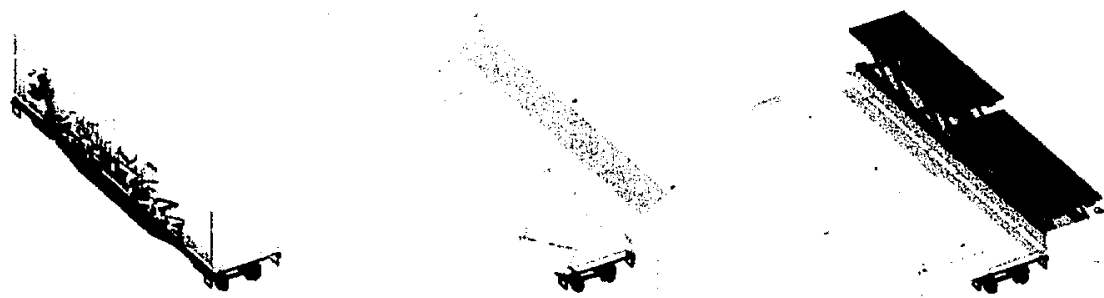

Fig. 39 Canvas Car: Deployment into a platform 

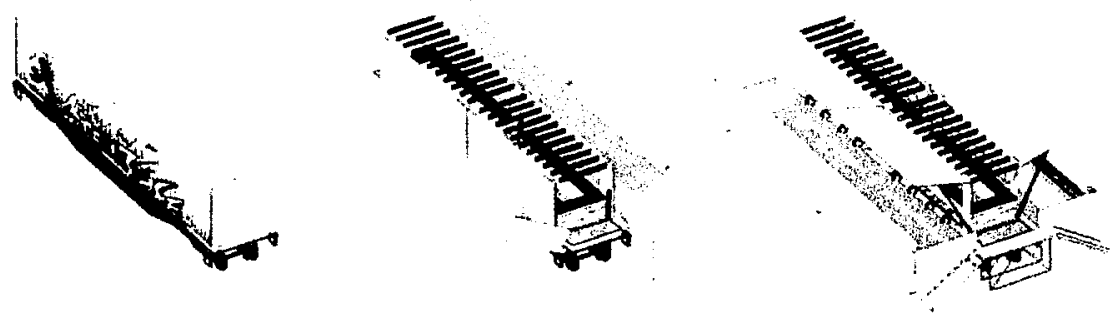

Fig. 40 Canvas Car: Deployment into a Bar
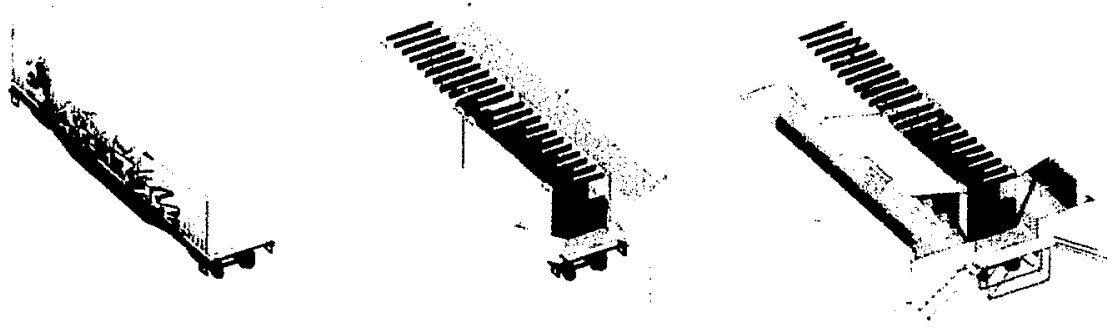

Fig. 41 Canvas Car: Deplovment into a Gift Shop 


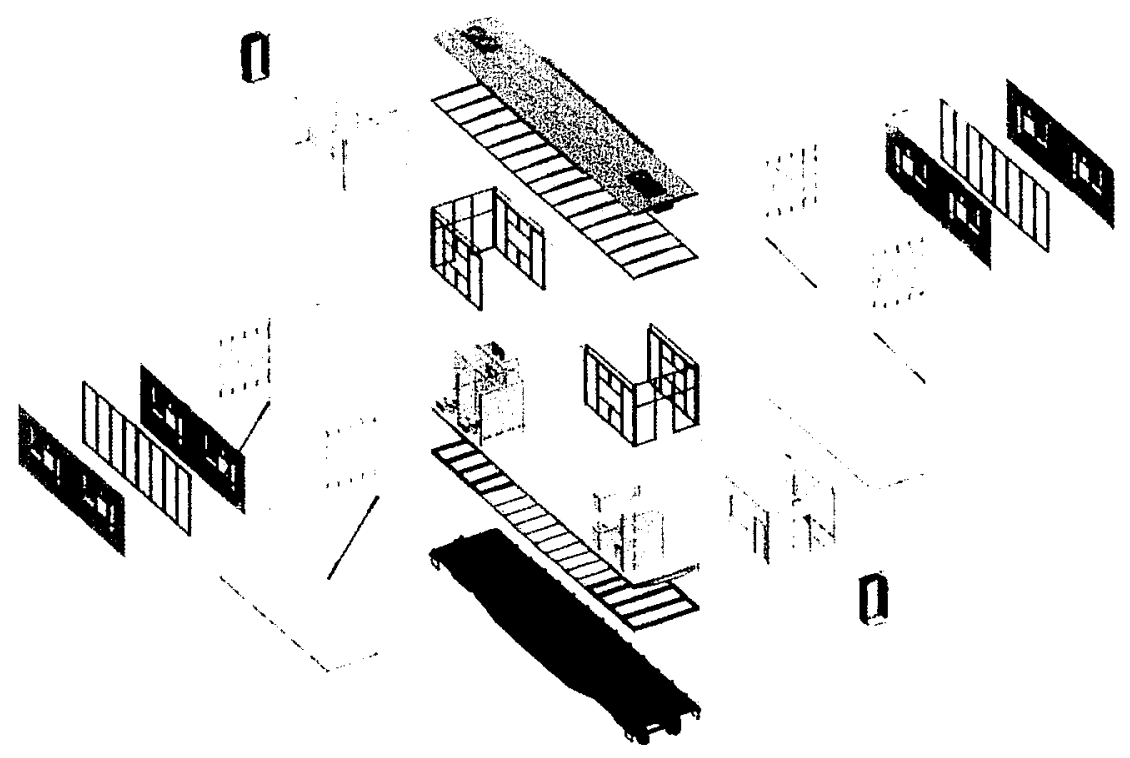

Fig. 42 Structural Components of a Sleeper Car: in the Residence Mode

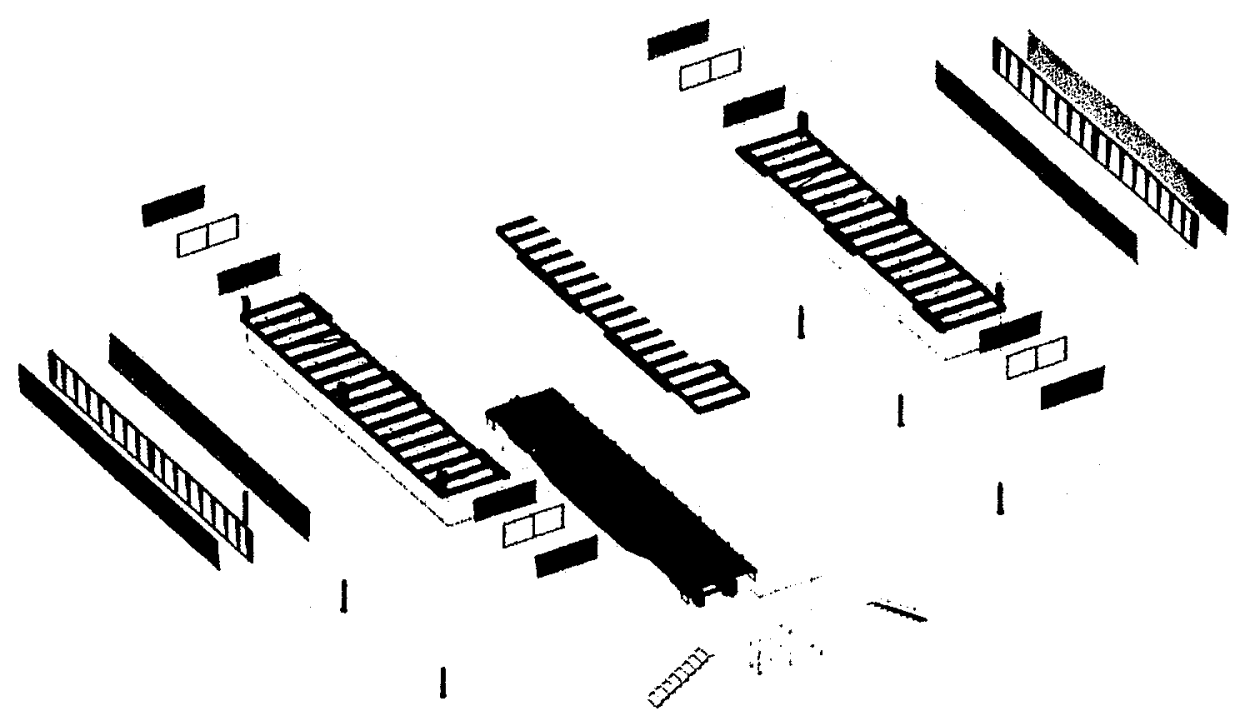

Fig. 43 Structural Components of a Canvas Car: in the Platform Mode 

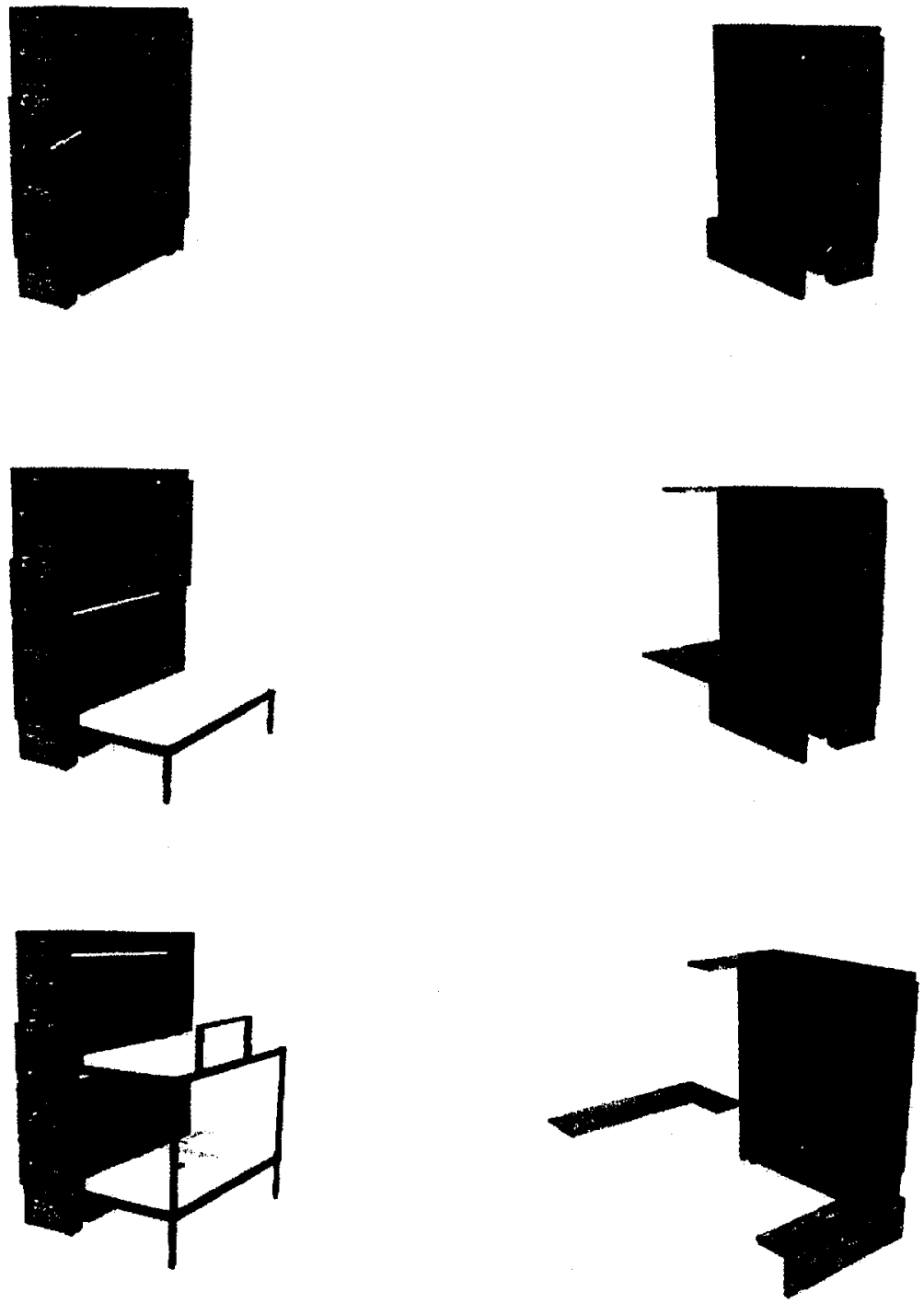

Fig. 44 Transformation of a Crate 


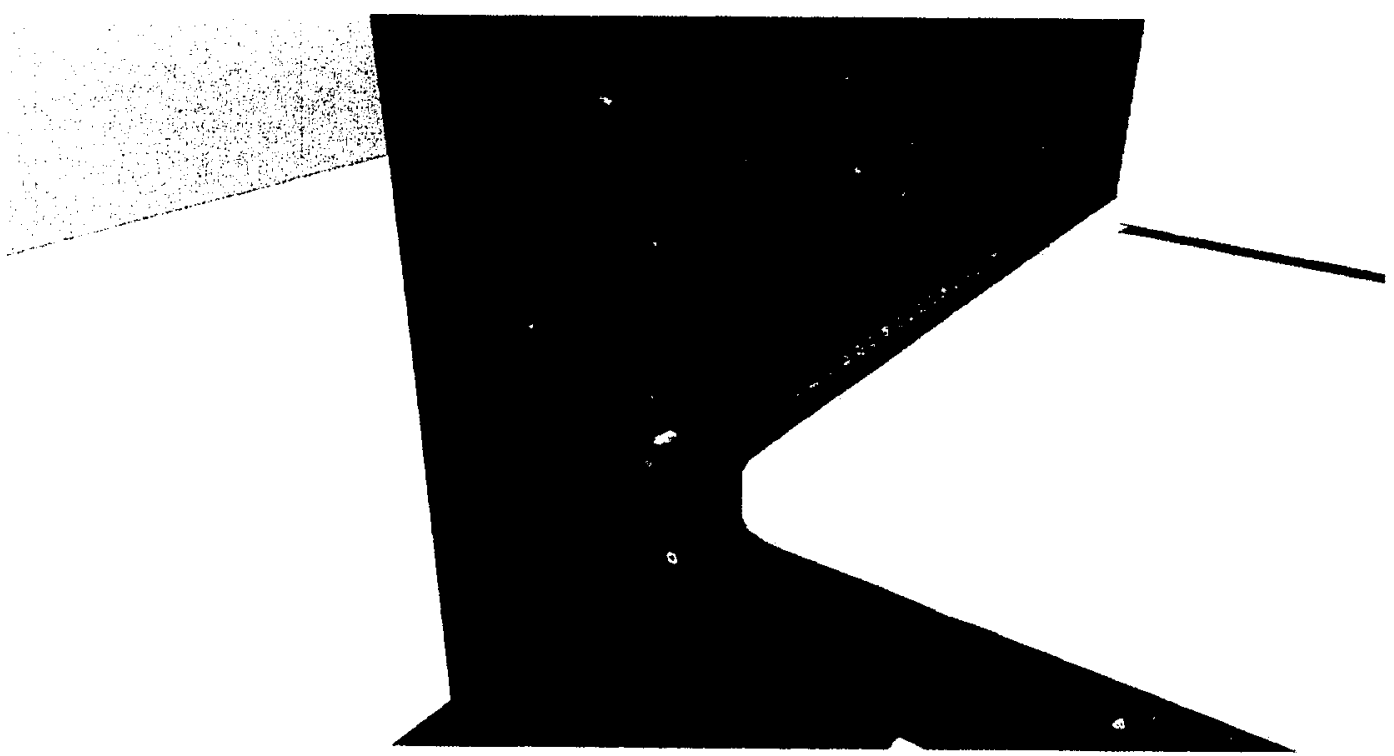

Fig. 45 Crate: Joinery Details

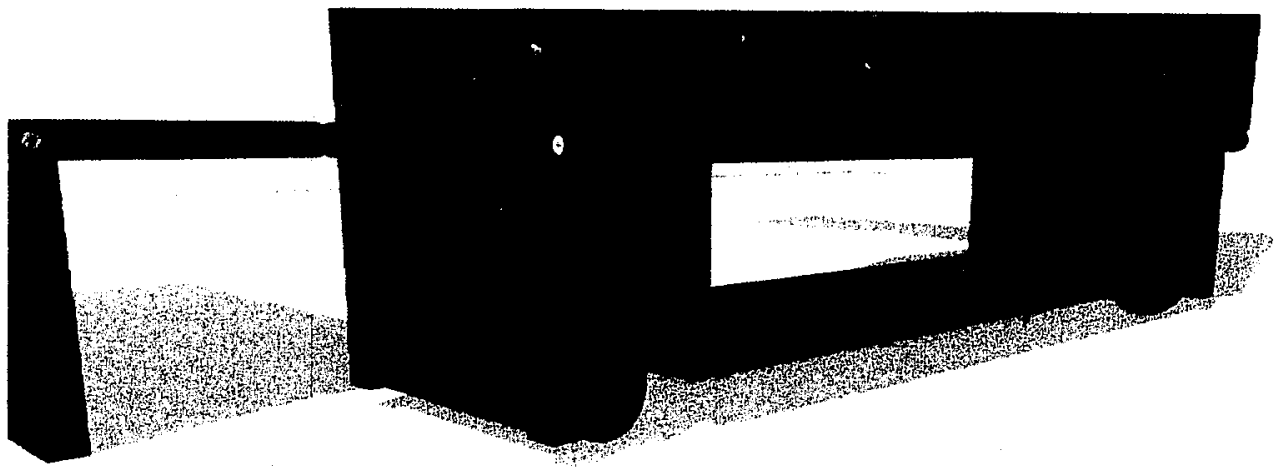

Fig. 46 Crate: Joinery Details 


\section{Track 10: The Legend Continues}

Railway legends haunt many Canadian hearts. In the early years of the formation of Canada, railroads held Canadian territory together; at the same time, it carried immigrants and settlers to different regions within the national boundary. Since the glory of the railway faded after the rise of automobiles and highways in the 1950's, CNR, VIA (Via Rail Canada) and CPR train models have still been found in almost every hobby store today. The obsession of reconstructing rail town remains an emotional attachment to our historical background and it is a process of self-identification.

Canadian identity is, according to Wyman's argument, established through the maintenance of diverse cultural expressions while affirming the cultural integrity of Canada. ${ }^{72}$ There is a need to enhance the awareness of Canada's cultural variety as a means to recognize who we are. Wyman's argument, together with Geertz's theory that cultural variety is best understood through the experience of art forms such as music, ${ }^{73}$ suggests the Canadian society needs a country-wide event in order for communities and ethnic groups to exchange their different aspirations and art expressions.

\footnotetext{
72 Wyman, Max. The Defiant Imagination: Why Culture Matters (Vancouver: Douglas \& Mclntyre Ltd., 2004 ), 8.

${ }^{73}$ Ibid., 18.
} 
The design of the annual music festival, 'Music Tracks,' will fulfill this need. 'Music Tracks' creates a national stage which acts as an outlet for diverse regional voices to be heard by larger populations. The festival sites of 'Music Tracks' enable cross-cultural interactions among the performers within musician colonies. The program of 'Music Tracks' sets up a framework for music performances to take places across the country and presents an opportunity to connect every Canadian heart through music. This musical odyssey fuses different regional voices to enrich cultural integrity. Although the old glory fades, 'Music Tracks,' will make the rusty railway shine again with a new spirit through a series of music events. We will be led on to a new chapter of the Canadian railway history. 


\section{Bibliography}

Barbara Bourget and Jay Hirabayashi.

http://www.kokoro.ca/biographies/jay_and_barbara.htm (accessed 04 2009).

Barry Bergdoll, Peter Christensen. Home Delivery. New York: The Museum of Modern Art, 2008.

Bellis, Mary. Henry Ford (1863-1947).

http://inventors.about.com/od/fstartinventors/a/HenryFord.htm (accessed $042009]$.

Berton, Pierre. The Last Spike: the Great Railway 1881-1885. Anchor Canada.

Blue Rodeo: Western Skies Lyrics. http://www.metrolyrics.com/western-skieslyrics-blue-rodeo.html (accessed 05 2009).

BNSF Railway. http://wwv.bnsf.com/ (accessed 03 2009).

Book of Days Lyrics. http://www.lyrics.com/index.php/artists/lyric/enya-lyricsbook-of-days-t-1469636 (accessed May 2009).

Brown, Ron. The Train Doesn't Stop Here Anymore: An Illustrated History of Railway Stations in Canada. 3rd. Toronto: Dundurn Press, 2008.

Canadian Pacific. Holiday Train. 2009. http://www8.cpr.ca/English/General+Public/Holiday+Train/default.htm (accessed 2009).

Canadian Pacific Railway Series 400000-999999.

http://www.nakina.net/cp/cp4.html (accessed 02 2009).

Clarkson, Adrienne. 3rd Session, Speech from the Throne. 2004. http://www2.parl.gc.ca/parlinfo/Documents/ThroneSpeech/37-1-e.html (accessed April 2009).

Clifford, Geertz. The Interpretation of Cultures: Selected Essays by Clifford Geertz. New York: A Member of the Perseus Books Group, 1973.

Frith, Simon. Performing Rites: on the Value of Popular Music. Cambridge, Massachusetts: Harvard Unviersity Press, 1996. 
Frye, Northrop, Robert D. Denham, David Staines, and Jean O'Grady. Northrop Frye on Canada. Toronto: University of Toronto Press, 2003.

Great Northern Way Campus. Great Northern Way Campus. 2008. http://www.gnwc.ca/ (accessed 04 14, 2009).

Greenlaw, Christopher C.N. VIA Rail. St. Paul: Voyageur Press, 2007.

Halbwachs, Maurice. On Collective Memory. Chicago: Univeristy of Chicago Press, 1992.

Heritage Research Associates Inc. Union/VIA Rail Station, Ottawa, Ontario. Railway Station Report, Historic Sites and Mounments Board of Canada.

Keillor, Elaine. Music in Canada. Quebec: McGill-Queen's Unviersity Press, 2006.

Kronenburg, Robert. Flexibie: Architecture that Responds to Change. London: Laurence King Publishing Ltd, 2007.

—. Houses in Motion. Chichester: Wiley-Academy, 2002.

—. Portable Architecture. Oxford: Architecture Press, 1996.

Let Go [Bonus disc]. http://www.lyrics.com/index.php/artists/lyric/avril-lavignelyrics-mobile (accessed 05 2009).

Loading Gauge. http://www.bookrags.com/wiki/Loading_gauge (accessed 02 2009).

Mystery Train. http://theband.hiof.no/lyrics/mystery_train.html (accessed 05 2009).

No Cars Go. http://www.lyricstime.com/arcade-fire-no-cars-go-lyrics.html (accessed 05 2009).

Ottawa Train Yards Inc. Ottawa Train Yards. 2009.

http://www.ottawatrainyards.com/future.html (accessed 03 11, 2009).

Pilar, Echavarria M. Portable Architecture - and upredictable Surroundings - Arian Mostaedi, 2006.

Rattenbu, Kester. Cedric Price: Potteries Thinkbelt: SuperCrit 1. Routledge, 2008.

Roger Gastman, Darin Rnwland, and lan Sattler. Freight Train Graffiti. New York: Harry N. Abrams, Inc., 2006.

Salloum, Habee. "Canada's Railroads." Contemporary Review, December 2002: 360364. 
Statistics Canada. Canada's ethnocultural portrait: The changing mosaic. http://www12.statcan.ca/english/census01/products/analytic/companion /etoimm/canada.cfm (accessed 0.1 29, 2009).

- Canada's ethnocultural portrait: The changing mosaic. http://www12.statcan.ca/english/census01/products/analytic/companion /etoimm/canada.cfm (accessed 04 2009).

STUFISH . STUFISH Mark Fisher Studio. 2009. http://www.stufish.com/aboutus $\mathrm{ml}$ (accessed 04 09, 2009).

The Festival : yress DVD.

The Sistine Chapel. http://mv.vatican.va/3_EN/pages/CSN/CSN_Main.html (accessed 05 2009).

Today in History: July 30 - Henry Ford. http://lcweb2.loc.gov/ammem/today/jul30.html (accessed 04 2009).

Uzume Taiko. http://www.uzume.com/ (accessed 03 2009).

Wyman, Max. The Defiant Imagination: Why Culture Matters. Vancouver: Douglas \& McIntyre Ltd., 2004. 